\title{
Discovery of Cysteine and Its Derivatives as Novel Antiviral and Antifungal Agents
}

\author{
Shan Yang ${ }^{1,+}$, Tienan Wang ${ }^{1,+}$, Yanan Zhou ${ }^{1}$, Li Shi $^{1}$, Aidang Lu ${ }^{1, *}$ and Ziwen Wang ${ }^{2, *(1)}$ \\ 1 School of Chemical Engineering and Technology, Hebei University of Technology, Tianjin 300130, China; \\ 17865513875@163.com (S.Y.); cdwangtienan@163.com (T.W.); zyn990611@163.com (Y.Z.); \\ s18310724767@163.com (L.S.) \\ 2 Tianjin Key Laboratory of Structure and Performance for Functional Molecules, College of Chemistry, Tianjin \\ Normal University, Tianjin 300387, China \\ * Correspondence: luaidang@hebut.edu.cn (A.L.); hxxywzw@tjnu.edu.cn (Z.W.); Tel.: +86-22-60202812 (A.L.); \\ +86-22-23766531 (Z.W.) \\ + These authors contributed equally to this work.
}

check for

updates

Citation: Yang, S.; Wang, T.; Zhou, Y.; Shi, L.; Lu, A.; Wang, Z. Discovery of Cysteine and Its Derivatives as Novel Antiviral and Antifungal Agents. Molecules 2021, 26, 383. https:/ / doi.org/10.3390/molecules2 6020383)

Academic Editor: Jih-Jung Chen Received: 23 December 2020 Accepted: 11 January 2021 Published: 13 January 2021

Publisher's Note: MDPI stays neutral with regard to jurisdictional clai$\mathrm{ms}$ in published maps and institutional affiliations.

Copyright: (C) 2021 by the authors. Licensee MDPI, Basel, Switzerland. This article is an open access article distributed under the terms and conditions of the Creative Commons Attribution (CC BY) license (https:// creativecommons.org/licenses/by/ $4.0 /)$.

\begin{abstract}
Based on the structure of the natural product cysteine, a series of thiazolidine-4-carboxylic acids were designed and synthesized. All target compounds bearing thiazolidine-4-carboxylic acid were characterized by ${ }^{1} \mathrm{H}-\mathrm{NMR},{ }^{13} \mathrm{C}-\mathrm{NMR}$, and HRMS techniques. The antiviral and antifungal activities of cysteine and its derivatives were evaluated in vitro and in vivo. The results of anti-TMV activity revealed that all compounds exhibited moderate to excellent activities against tobacco mosaic virus (TMV) at the concentration of $500 \mu \mathrm{g} / \mathrm{mL}$. The compounds cysteine (1), 3-4, 7, 10, 13, 20, 23, and 24 displayed higher anti-TMV activities than the commercial plant virucide ribavirin (inhibitory rate: 40,40 , and $38 \%$ at $500 \mu \mathrm{g} / \mathrm{mL}$ for inactivation, curative, and protection activity in vivo, respectively), especially compound 3 (inhibitory rate: $51 \%, 47 \%$, and $49 \%$ at $500 \mu \mathrm{g} / \mathrm{mL}$ for inactivation, curative, and protection activity in vivo, respectively) with excellent antiviral activity emerged as a new antiviral candidate. Antiviral mechanism research by TEM exhibited that compound 3 could inhibit virus assembly by aggregated the $20 \mathrm{~S}$ protein disk. Molecular docking results revealed that compound 3 with higher antiviral activities than that of compound $\mathbf{2 4}$ did show stronger interaction with TMV CP. Further fungicidal activity tests against 14 kinds of phytopathogenic fungi revealed that these cysteine derivatives displayed broad-spectrum fungicidal activities. Compound 16 exhibited higher antifungal activities against Cercospora arachidicola Hori and Alternaria solani than commercial fungicides carbendazim and chlorothalonil, which emerged as a new candidate for fungicidal research.
\end{abstract}

Keywords: natural product; cysteine and its derivatives; anti-TMV activity; antifungal activity; mode of action; molecular docking

\section{Introduction}

Fungal and viral pathogens can induce various of plant diseases such as those causing brown spots on peanut leaves, ring rots on stem and fruit of apples, gray mold on cucumbers and grapes, leading to huge losses to agriculture and horticulture production and threatening food security [1]. Tobacco mosaic virus (TMV), known as "plant cancer", not only can seriously harm tobacco, but also can infect potato, pepper, tomato, eggplant, nightshade, and more than 400 other plant species [2,3]. The long-term, large-scale use of traditional high-toxic pesticides not only forces bacteria and viruses to develop resistance, but also poses a threat to human health. The development of new antifungal and antiviral agents with unique mode of action is becoming more and more urgent for plant protection and agricultural production [4-6].

Amino acids are substances that exist widely in Nature. Cysteine is the only sulfurcontaining amino acid with the ability to form disulfide bonds. Due to the bigger atomic 
radius of sulfur and the lower dissociation energy of the $\mathrm{S}-\mathrm{H}$ bond, the thiol group of cysteine possesses the ability to perform both nucleophilic and redox-active functions which are unfeasible for the other natural amino acids [7-9]. Cysteine, with its easily modified molecular structure, has attracted attention from biological and chemical scientists. A series of biological activities of cysteine and its derivatives have been reported, such as cytotoxicity [10], neurotoxicity [11-13], oxidant activity [14], accelerated DNA oxidative damage [15], and so on.

Heterocycles are an important framework for the development of new drugs, especially S-containing heterocycles which have been found to have the ability to induce apoptosis of various cells [16]. Thiazolidine drugs containing $\mathrm{N}$ and $\mathrm{S}$ atoms can exert drug effects through various mechanisms of action, such as inhibiting neuraminidase of influenza A virus [17], inhibiting protein synthesis [18], accelerating cell apoptosis [16,19], enhancing antioxidant capacity [7], immune stimulation [20], etc. Some thiazolidine4-carboxylic acid derivatives can also oxidatively cleave DNA and interact with metal ions [21]. Some thiazolidine derivatives have been used in a variety of synthetic modifications due to their simple structure, diverse biological characteristics, and excellent environmental compatibility [22,23].

It is an important research direction for us to find effective antiviral candidates based on natural products [24]. In our previous work, a series of amino acid gossypol Schiff bases were designed and synthesized. The structure-activity relationship revealed that both the carboxy group and substituents in amino acids had significant effect on antiTMV [25]. Combined with our existing work experience and the above findings, we made systematic research on cysteine and its derivatives (Figure 1) in the present work. All synthetic compounds were characterized by ${ }^{1} \mathrm{H}-\mathrm{NMR},{ }^{13} \mathrm{C}-\mathrm{NMR}$, and HRMS. The antiviral and antifungal activities of these compounds and the structure-activity relationship were evaluated systematically.

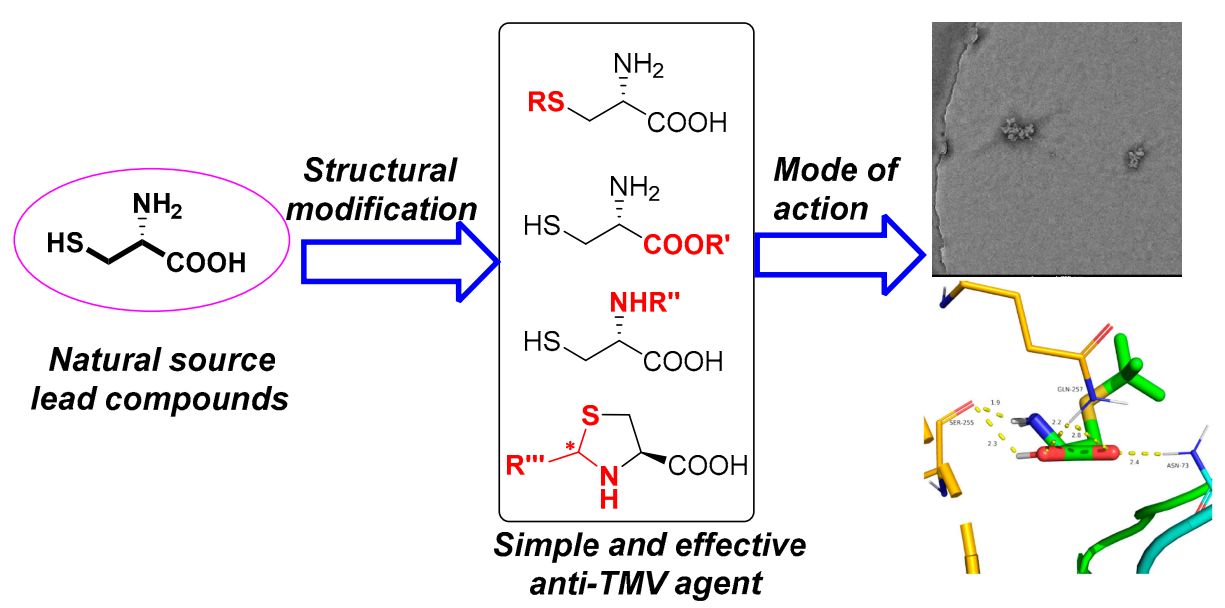

Figure 1. Design of cysteine derivatives.

\section{Results}

\subsection{Chemistry}

Cysteine and its derivatives 1-7 (Figure 2) were purchased directly. A series of thiazole ring containing L-cysteine derivatives 8-24 were designed and synthesized from L-cysteine and different substituted aldehydes (Scheme 1) by a one-pot method $[7,26]$. 
<smiles>N[C@@H](CS)C(=O)O</smiles>

1-D<smiles>CC(C)SC[C@H](N)C(=O)O</smiles>

3<smiles>CC(=O)N[C@@H](CS)C(=O)O</smiles><smiles>N[C@@H](CS)C(=O)O</smiles><smiles>N[C@@H](CSBr)C(=O)O</smiles>

4<smiles>[Z20]C(CSC)C(N)CSC</smiles><smiles>COC(=O)[C@H](N)Cl</smiles><smiles>CCOC(=O)[C@H](N)CS</smiles>

5

Figure 2. Structures of compounds 1-7.

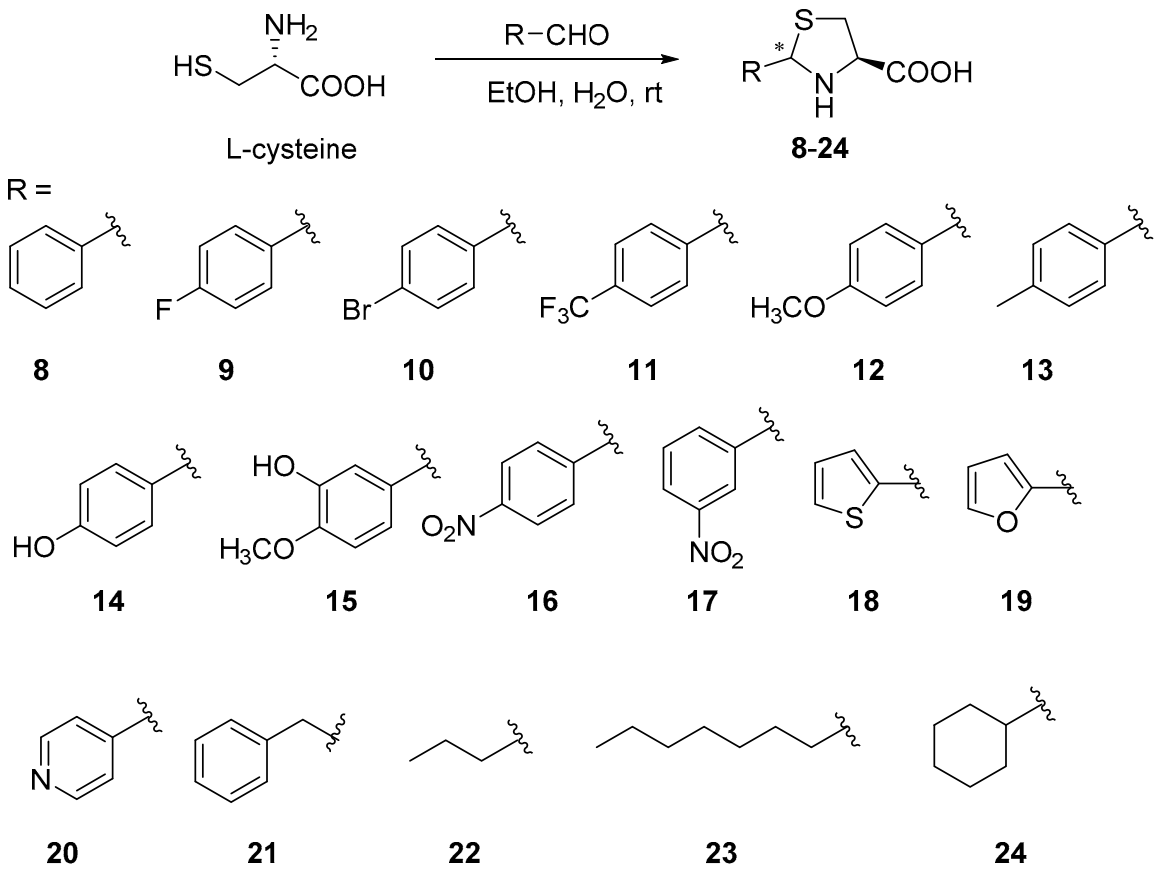

Scheme 1. Synthesis of 8-24.

\subsection{Phytotoxic Activity}

The phytotoxicity-activity tests revealed that cysteine and its derivatives were safe for testing on plants at $500 \mu \mathrm{g} / \mathrm{mL}$. The detailed test procedures can be seen in our previous reports $[5,27]$. The detailed test procedures can also be found in the Supplementary Materials.

\subsection{Antiviral Activity}

\subsubsection{In Vitro Anti-TMV Activity}

The anti-TMV activities of cysteine and its derivatives 1-24 are listed in Table 1 with the commercial drugs ribavirin and ningnanmycin as controls. Compounds 1-7 had better antiTMV activities than ribavirin. Among compounds 1-7, compounds 3 (inhibitory rate: $48 \%$ at $500 \mu \mathrm{g} / \mathrm{mL}$ ) and 4 (inhibitory rate: $45 \%$ at $500 \mu \mathrm{g} / \mathrm{mL}$ ) showed better anti-TMV activities than the others. At the concentration of $100 \mu \mathrm{g} / \mathrm{mL}$, compounds 3 (inhibitory rate: 13\%) and 4 (inhibitory rate: $12 \%$ ) also displayed better anti-TMV activities than the commercial plant virucide ribavirin (inhibitory rate: 7\%). Most of the cysteine derivatives 8-24 with thiazolidine structure exhibited better anti-TMV activities than that of the commercial plant 
virucide ribavirin. Especially, compounds 23 (inhibitory rate: $46 \%$ at $500 \mu \mathrm{g} / \mathrm{mL}$ ) and 24 (inhibitory rate: $45 \%$ at $500 \mu \mathrm{g} / \mathrm{mL}$ ) showed 10\% higher anti-TMV activity than ribavirin (inhibitory rate: $35 \%$ at $500 \mu \mathrm{g} / \mathrm{mL}$ ).

Table 1. In vitro antiviral activity of compounds 1-24 against TMV.

\begin{tabular}{|c|c|c|c|c|c|}
\hline Compd. & Concn $(\mu \mathrm{g} / \mathrm{mL})$ & Inhibition Rate $(\%)^{a}$ & Compd. & Concn $(\mu \mathrm{g} / \mathrm{mL})$ & Inhibition Rate $(\%)^{a}$ \\
\hline \multirow{2}{*}{ 1-D } & 500 & $39 \pm 3$ & \multirow[b]{2}{*}{13} & 500 & $43 \pm 1$ \\
\hline & 100 & $13 \pm 2$ & & 100 & $17 \pm 1$ \\
\hline \multirow{2}{*}{ 1-L } & 500 & $41 \pm 2$ & \multirow{2}{*}{14} & 500 & $18 \pm 2$ \\
\hline & 100 & $11 \pm 1$ & & 100 & 0 \\
\hline \multirow{2}{*}{ 2-D } & 500 & $38 \pm 2$ & \multirow{2}{*}{15} & 500 & $34 \pm 1$ \\
\hline & 100 & $15 \pm 2$ & & 100 & $12 \pm 1$ \\
\hline \multirow{2}{*}{ 2-L } & 500 & $40 \pm 1$ & \multirow{2}{*}{16} & 500 & $40 \pm 2$ \\
\hline & 100 & $16 \pm 2$ & & 100 & $16 \pm 2$ \\
\hline \multirow[b]{2}{*}{3} & 500 & $48 \pm 1$ & \multirow[b]{2}{*}{17} & 500 & $39 \pm 1$ \\
\hline & 100 & $13 \pm 2$ & & 100 & $14 \pm 2$ \\
\hline \multirow{2}{*}{4} & 500 & $45 \pm 2$ & \multirow{2}{*}{18} & 500 & $24 \pm 2$ \\
\hline & 100 & $12 \pm 1$ & & 100 & 0 \\
\hline \multirow{2}{*}{5} & 500 & $42 \pm 2$ & \multirow{2}{*}{19} & 500 & $32 \pm 2$ \\
\hline & 100 & $10 \pm 1$ & & 100 & 0 \\
\hline \multirow{2}{*}{6} & 500 & $40 \pm 2$ & \multirow{2}{*}{20} & 500 & $43 \pm 2$ \\
\hline & 100 & $20 \pm 1$ & & 100 & $18 \pm 2$ \\
\hline \multirow[b]{2}{*}{7} & 500 & $44 \pm 2$ & \multirow[b]{2}{*}{21} & 500 & $35 \pm 2$ \\
\hline & 100 & $22 \pm 1$ & & 100 & $11 \pm 1$ \\
\hline \multirow[b]{2}{*}{8} & 500 & $33 \pm 2$ & \multirow{2}{*}{22} & 500 & $33 \pm 1$ \\
\hline & 100 & $9 \pm 2$ & & 100 & $10 \pm 1$ \\
\hline \multirow[b]{2}{*}{9} & 500 & $35 \pm 1$ & \multirow{2}{*}{23} & 500 & $46 \pm 1$ \\
\hline & 100 & $12 \pm 2$ & & 100 & $17 \pm 2$ \\
\hline \multirow[b]{2}{*}{10} & 500 & $39 \pm 2$ & \multirow[b]{2}{*}{24} & 500 & $45 \pm 1$ \\
\hline & 100 & $13 \pm 1$ & & 100 & $19 \pm 1$ \\
\hline \multirow{2}{*}{11} & 500 & $43 \pm 1$ & \multirow{2}{*}{ Ribavirin } & 500 & $35 \pm 1$ \\
\hline & 100 & $19 \pm 1$ & & 100 & $7 \pm 1$ \\
\hline \multirow{2}{*}{12} & 500 & $38 \pm 2$ & \multirow{2}{*}{ Ningnanmycin } & 500 & $61 \pm 2$ \\
\hline & 100 & $16 \pm 1$ & & 100 & $23 \pm 2$ \\
\hline
\end{tabular}

${ }^{a}$ Average of three replicates. All results are expressed as mean \pm SD.

\subsubsection{In Vivo Anti-TMV Activity}

In vivo anti-TMV activity includes three test modes: inactivation, curative, and protection. As shown in Table 2, most of the compounds also displayed higher in vivo activities than ribavirin. Compound 3 displayed the best anti-TMV activity at $500 \mu \mathrm{g} / \mathrm{mL}$ (inactivation activity, 51\%; curative activity, 47\%; protection activity, 49\%), which is significantly higher than that of ribavirin (inactivation activity, $40 \%$; curative activity, $40 \%$; protection activity, 38\%).

\subsection{Mode of Action Studies}

2.4.1. Preliminary Mode of Action

Preliminary mode of action revealed that these compounds can inhibit the assembly of TMV. The detailed method was described in the literature [24] and also can be found in the Supporting Materials. 
Table 2. In Vivo antiviral activity of compounds 1-24 against TMV.

\begin{tabular}{|c|c|c|c|c|}
\hline Compd. & Concn $(\mu \mathrm{g} / \mathrm{mL})$ & Inactivation Effect (\%) ${ }^{a}$ & Curative Effect (\%) ${ }^{a}$ & Protection Effect (\%) ${ }^{a}$ \\
\hline \multirow{2}{*}{ 1-D } & 500 & $44 \pm 2$ & $38 \pm 2$ & $37 \pm 1$ \\
\hline & 100 & $18 \pm 3$ & $15 \pm 2$ & $14 \pm 1$ \\
\hline \multirow{2}{*}{ 1-L } & 500 & $43 \pm 1$ & $42 \pm 2$ & $40 \pm 1$ \\
\hline & 100 & $20 \pm 2$ & $16 \pm 1$ & $13 \pm 2$ \\
\hline \multirow{2}{*}{ 2-D } & 500 & $37 \pm 2$ & $41 \pm 3$ & $36 \pm 1$ \\
\hline & 100 & $12 \pm 1$ & $13 \pm 1$ & $15 \pm 2$ \\
\hline \multirow{2}{*}{ 2-L } & 500 & $39 \pm 1$ & $40 \pm 2$ & $38 \pm 2$ \\
\hline & 100 & $11 \pm 2$ & $14 \pm 1$ & $12 \pm 1$ \\
\hline \multirow{2}{*}{3} & 500 & $51 \pm 2$ & $47 \pm 2$ & $49 \pm 2$ \\
\hline & 100 & $26 \pm 1$ & $23 \pm 1$ & $25 \pm 1$ \\
\hline \multirow[b]{2}{*}{4} & 500 & $45 \pm 1$ & $43 \pm 1$ & $46 \pm 1$ \\
\hline & 100 & $18 \pm 2$ & $20 \pm 2$ & $22 \pm 2$ \\
\hline \multirow{2}{*}{5} & 500 & $40 \pm 1$ & $39 \pm 2$ & $37 \pm 2$ \\
\hline & 100 & $13 \pm 1$ & $16 \pm 1$ & $16 \pm 1$ \\
\hline \multirow{2}{*}{6} & 500 & $38 \pm 2$ & $40 \pm 2$ & $35 \pm 2$ \\
\hline & 100 & $16 \pm 2$ & $16 \pm 1$ & $16 \pm 1$ \\
\hline \multirow[b]{2}{*}{7} & 500 & $44 \pm 1$ & $42 \pm 2$ & $41 \pm 2$ \\
\hline & 100 & $20 \pm 2$ & $16 \pm 1$ & $18 \pm 1$ \\
\hline \multirow{2}{*}{8} & 500 & $37 \pm 2$ & $33 \pm 2$ & $35 \pm 2$ \\
\hline & 100 & $11 \pm 1$ & $10 \pm 1$ & $11 \pm 1$ \\
\hline \multirow{2}{*}{9} & 500 & $36 \pm 2$ & $35 \pm 1$ & $34 \pm 1$ \\
\hline & 100 & $10 \pm 1$ & $9 \pm 1$ & $9 \pm 1$ \\
\hline \multirow{2}{*}{10} & 500 & $41 \pm 2$ & $40 \pm 2$ & $41 \pm 2$ \\
\hline & 100 & $10 \pm 1$ & $10 \pm 1$ & $13 \pm 1$ \\
\hline \multirow{2}{*}{11} & 500 & $40 \pm 2$ & $39 \pm 2$ & $40 \pm 2$ \\
\hline & 100 & $15 \pm 1$ & $17 \pm 1$ & $12 \pm 1$ \\
\hline \multirow[b]{2}{*}{12} & 500 & $43 \pm 2$ & $36 \pm 2$ & $41 \pm 2$ \\
\hline & 100 & $14 \pm 1$ & $13 \pm 1$ & $15 \pm 1$ \\
\hline \multirow{2}{*}{13} & 500 & $49 \pm 2$ & $46 \pm 2$ & $44 \pm 2$ \\
\hline & 100 & $18 \pm 2$ & $15 \pm 2$ & $13 \pm 2$ \\
\hline \multirow{2}{*}{14} & 500 & $21 \pm 2$ & $17 \pm 2$ & $15 \pm 2$ \\
\hline & 100 & 0 & 0 & 0 \\
\hline \multirow{2}{*}{15} & 500 & $28 \pm 2$ & $33 \pm 2$ & $25 \pm 2$ \\
\hline & 100 & $9 \pm 1$ & $11 \pm 1$ & $7 \pm 1$ \\
\hline \multirow{2}{*}{16} & 500 & $42 \pm 1$ & $37 \pm 1$ & $35 \pm 1$ \\
\hline & 100 & 0 & 0 & 0 \\
\hline \multirow{2}{*}{17} & 500 & $40 \pm 1$ & $36 \pm 1$ & $35 \pm 1$ \\
\hline & 100 & 0 & 0 & 0 \\
\hline \multirow{2}{*}{18} & 500 & $24 \pm 2$ & $23 \pm 2$ & $20 \pm 2$ \\
\hline & 100 & 0 & 0 & 0 \\
\hline \multirow{2}{*}{19} & 500 & $34 \pm 2$ & $30 \pm 2$ & $36 \pm 2$ \\
\hline & 100 & 0 & 0 & 0 \\
\hline \multirow[b]{2}{*}{20} & 500 & $47 \pm 2$ & $45 \pm 2$ & $43 \pm 2$ \\
\hline & 100 & $21 \pm 2$ & $19 \pm 2$ & $14 \pm 2$ \\
\hline & 500 & $37 \pm 2$ & $40 \pm 2$ & $34 \pm 2$ \\
\hline 21 & 100 & $11 \pm 2$ & $15 \pm 2$ & $11 \pm 2$ \\
\hline & 500 & $33 \pm 2$ & $37 \pm 2$ & $32 \pm 2$ \\
\hline 22 & 100 & $10 \pm 2$ & $13 \pm 2$ & $9 \pm 2$ \\
\hline
\end{tabular}


Table 2. Cont.

\begin{tabular}{|c|c|c|c|c|}
\hline Compd. & Concn $(\mu \mathrm{g} / \mathrm{mL})$ & Inactivation Effect (\%) ${ }^{a}$ & Curative Effect $(\%)^{a}$ & Protection Effect $(\%)^{a}$ \\
\hline \multirow{2}{*}{23} & 500 & $48 \pm 1$ & $49 \pm 1$ & $47 \pm 1$ \\
\hline & 100 & $19 \pm 2$ & $15 \pm 2$ & $17 \pm 2$ \\
\hline \multirow{2}{*}{24} & 500 & $47 \pm 1$ & $42 \pm 1$ & $43 \pm 1$ \\
\hline & 100 & $15 \pm 1$ & $17 \pm 1$ & $15 \pm 1$ \\
\hline \multirow{2}{*}{ Ribavirin } & 500 & $40 \pm 1$ & $40 \pm 1$ & $38 \pm 1$ \\
\hline & 100 & $13 \pm 1$ & $15 \pm 1$ & $10 \pm 1$ \\
\hline \multirow{2}{*}{ Ningnanmycin } & 500 & $56 \pm 2$ & $53 \pm 2$ & $59 \pm 1$ \\
\hline & 100 & $28 \pm 1$ & $24 \pm 1$ & $30 \pm 1$ \\
\hline
\end{tabular}

${ }^{\text {a }}$ Average of three replicates. All results are expressed as mean \pm SD.

\subsubsection{Docking Studies}

To further study the mechanism of the interaction between cysteines and TMV CP, we chose AutoDock Vina 1.1.2 for molecular docking [28]. The docking poses are ranked according to their docking sites and the lowest binding energy of macromolecule-ligand complex is considered being the best. It can be proved H-bond interaction and strong binding affinity between cysteines and TMV CP.

\subsection{Fungicidal Activity}

\subsubsection{In Vitro Fungicidal Activity}

We further tested the inhibitory effects of compounds 1-24 on 14 common agricultural pathogens at a concentration of $50 \mu \mathrm{g} / \mathrm{mL}$ using fungicidal growth rate assay [27,29] with commercial fungicidal agents chlorothalonil and carbendazim as controls. All compounds showed broad-spectrum fungicidal activities (Table 3). Compound $\mathbf{1 6}$ exhibited higher antifungal activities against Cercospora arachidicola Hori (inhibitory rate: $71 \%$ ) and Alternaria solani (inhibitory rate: 58\%) than commercial fungicides carbendazim and chlorothalonil. Compound 16 had an inhibitory rate of $83 \%$ against Physalospora piricola.

\subsubsection{In Vivo Fungicidal Activity}

Compounds 1-24 were further tested in vivo fungicidal activity at a concentration of $200 \mu \mathrm{g} / \mathrm{mL}$ using standard methods [29] with azoxystrobin as a control against Blumeria graminis f.sp. tritici, Sclerotinia sclerotiorum, Botrytis cinereal, Rhizoctonia solani, Corynespora cassiicola, and Phytophthora capsica 6 kinds of pathogenic fungi. As shown in Table 4, most of these compounds also displayed broad-spectrum in vivo fungicidal activities. Compounds $\mathbf{1 2}$ and $\mathbf{1 8}$ showed 20\% inhibition rate against Rhizoctonia solani. Compound $\mathbf{1 2}$ exhibited higher activity than other compounds against Botrytis cinereal. The inhibition rate of compound $\mathbf{1 8}$ is more than $20 \%$ against Corynespora cassiicola. 
Table 3. In vitro fungicidal activities of compounds 1-24 against 14 kinds of fungi.

\begin{tabular}{|c|c|c|c|c|c|c|c|c|c|c|c|c|c|c|}
\hline \multirow{2}{*}{ Compd. } & \multicolumn{14}{|c|}{ Fungicidal Activity (\%) ${ }^{\text {a }}$ at $50 \mu \mathrm{g} / \mathrm{mL}$} \\
\hline & $F . C^{\mathbf{b}}$ & $C . H^{\mathrm{b}}$ & $P . P^{\mathrm{b}}$ & R.C ${ }^{b}$ & $B \cdot M^{\mathrm{b}}$ & $W \cdot A^{\mathrm{b}}$ & $F . M^{b}$ & $A . S^{\mathbf{b}}$ & $F \cdot G^{\mathbf{b}}$ & $P . I^{\mathrm{b}}$ & $P . C^{\mathbf{b}}$ & $S . S^{\mathbf{b}}$ & $B . C^{\mathbf{b}}$ & $R . S^{b}$ \\
\hline 1-D & $18 \pm 2$ & $7 \pm 1$ & $30 \pm 2$ & $9 \pm 1$ & $10 \pm 2$ & $11 \pm 3$ & $9 \pm 1$ & $37 \pm 3$ & $16 \pm 2$ & $8 \pm 2$ & $27 \pm 3$ & $20 \pm 1$ & $16 \pm 2$ & $11 \pm 1$ \\
\hline 1-L & $16 \pm 1$ & $5 \pm 1$ & $35 \pm 1$ & $11 \pm 1$ & $7 \pm 2$ & $16 \pm 1$ & $6 \pm 1$ & $35 \pm 1$ & $10 \pm 2$ & $10 \pm 1$ & $22 \pm 1$ & $25 \pm 1$ & $18 \pm 1$ & $12 \pm 1$ \\
\hline 2-D & $13 \pm 1$ & $19 \pm 2$ & $25 \pm 2$ & $12 \pm 1$ & $26 \pm 2$ & $30 \pm 2$ & $16 \pm 1$ & $42 \pm 1$ & $24 \pm 1$ & $13 \pm 1$ & $16 \pm 1$ & $31 \pm 3$ & $24 \pm 1$ & $17 \pm 2$ \\
\hline 2-L & $18 \pm 1$ & $13 \pm 2$ & $29 \pm 2$ & $15 \pm 1$ & $21 \pm 2$ & $33 \pm 2$ & $19 \pm 1$ & $49 \pm 2$ & $26 \pm 1$ & $13 \pm 1$ & $17 \pm 1$ & $36 \pm 2$ & $21 \pm 1$ & $14 \pm 1$ \\
\hline 3 & $11 \pm 1$ & $13 \pm 1$ & $22 \pm 1$ & $26 \pm 2$ & $10 \pm 1$ & $11 \pm 1$ & $13 \pm 1$ & $39 \pm 1$ & $13 \pm 1$ & $15 \pm 1$ & $21 \pm 1$ & $23 \pm 1$ & $17 \pm 1$ & $16 \pm 1$ \\
\hline 4 & $9 \pm 1$ & $7 \pm 1$ & $31 \pm 1$ & $16 \pm 1$ & $13 \pm 2$ & $22 \pm 1$ & $16 \pm 1$ & $36 \pm 1$ & $13 \pm 2$ & $15 \pm 2$ & $12 \pm 1$ & $19 \pm 1$ & $10 \pm 1$ & $17 \pm 2$ \\
\hline 5 & $23 \pm 1$ & $16 \pm 2$ & $35 \pm 1$ & $10 \pm 1$ & $23 \pm 2$ & $16 \pm 1$ & $24 \pm 1$ & $42 \pm 1$ & $10 \pm 1$ & $13 \pm 1$ & $17 \pm 1$ & $29 \pm 1$ & $14 \pm 1$ & $13 \pm 2$ \\
\hline 6 & $12 \pm 1$ & $18 \pm 1$ & $41 \pm 1$ & $36 \pm 1$ & $26 \pm 2$ & $19 \pm 2$ & $15 \pm 1$ & $43 \pm 1$ & $13 \pm 1$ & $11 \pm 1$ & $17 \pm 1$ & $21 \pm 1$ & $8 \pm 1$ & $13 \pm 1$ \\
\hline 7 & $37 \pm 1$ & $15 \pm 1$ & $32 \pm 1$ & $42 \pm 1$ & $25 \pm 1$ & $19 \pm 1$ & $23 \pm 1$ & $46 \pm 1$ & $17 \pm 1$ & $13 \pm 1$ & $34 \pm 1$ & $19 \pm 1$ & $22 \pm 1$ & $17 \pm 1$ \\
\hline 8 & $10 \pm 1$ & $14 \pm 1$ & $14 \pm 1$ & $9 \pm 1$ & $7 \pm 1$ & $16 \pm 1$ & $6 \pm 2$ & $42 \pm 1$ & $42 \pm 1$ & $16 \pm 1$ & $12 \pm 1$ & $19 \pm 2$ & $14 \pm 1$ & $6 \pm 1$ \\
\hline 9 & $16 \pm 1$ & $14 \pm 1$ & $17 \pm 1$ & $5 \pm 1$ & $17 \pm 1$ & $12 \pm 1$ & $18 \pm 1$ & $39 \pm 1$ & $32 \pm 2$ & $10 \pm 2$ & $6 \pm 1$ & $25 \pm 1$ & $13 \pm 1$ & $8 \pm 1$ \\
\hline 10 & $29 \pm 1$ & $52 \pm 2$ & $62 \pm 1$ & $28 \pm 1$ & $14 \pm 2$ & $32 \pm 1$ & $18 \pm 2$ & $39 \pm 1$ & $32 \pm 1$ & $10 \pm 1$ & $12 \pm 1$ & $13 \pm 1$ & $9 \pm 1$ & $16 \pm 1$ \\
\hline 11 & $19 \pm 2$ & $14 \pm 1$ & $24 \pm 1$ & $12 \pm 1$ & $7 \pm 1$ & $16 \pm 1$ & $18 \pm 2$ & $39 \pm 2$ & $13 \pm$ & $10 \pm 1$ & $10 \pm 1$ & $31 \pm 1$ & $4 \pm 1$ & $23 \pm 1$ \\
\hline 12 & $29 \pm 1$ & $19 \pm 1$ & $10 \pm 1$ & $11 \pm 2$ & $14 \pm 2$ & $24 \pm 2$ & $24 \pm 1$ & $23 \pm 1$ & $10 \pm 1$ & $13 \pm 2$ & $14 \pm 1$ & $19 \pm 2$ & $13 \pm 1$ & $12 \pm 1$ \\
\hline 13 & $26 \pm 1$ & $10 \pm 1$ & $38 \pm 2$ & $9 \pm 1$ & $17 \pm 1$ & $16 \pm 1$ & $12 \pm 1$ & $39 \pm 1$ & $10 \pm 1$ & $3 \pm 1$ & $12 \pm 1$ & $25 \pm 1$ & $11 \pm 1$ & $6 \pm 1$ \\
\hline 14 & $13 \pm 1$ & 0 & $17 \pm 1$ & 0 & $10 \pm 1$ & $12 \pm 1$ & $6 \pm 1$ & $42 \pm 1$ & $16 \pm 1$ & $7 \pm 1$ & $8 \pm 1$ & $25 \pm 1$ & $13 \pm 1$ & $8 \pm 1$ \\
\hline 17 & $16 \pm 1$ & $10 \pm 1$ & $38 \pm 1$ & $18 \pm 1$ & $10 \pm 1$ & $20 \pm 1$ & $12 \pm 1$ & $31 \pm 1$ & $10 \pm 1$ & $13 \pm 2$ & $16 \pm 1$ & $44 \pm 2$ & $18 \pm 1$ & $8 \pm 1$ \\
\hline 18 & $16 \pm 1$ & $48 \pm 1$ & $45 \pm 2$ & $23 \pm 2$ & $10 \pm 1$ & $20 \pm 1$ & $18 \pm 1$ & $27 \pm 1$ & $19 \pm 1$ & $10 \pm 1$ & $20 \pm 1$ & $31 \pm 1$ & $7 \pm 1$ & $12 \pm 1$ \\
\hline 19 & $48 \pm 2$ & $33 \pm 1$ & $45 \pm 1$ & $19 \pm 1$ & $10 \pm 1$ & $36 \pm 1$ & $35 \pm 1$ & $35 \pm 2$ & $13 \pm 2$ & $7 \pm 1$ & $29 \pm 1$ & $13 \pm 1$ & $11 \pm 1$ & $6 \pm 1$ \\
\hline 20 & $26 \pm 1$ & $10 \pm 1$ & $21 \pm 1$ & $12 \pm 1$ & $3 \pm 2$ & $16 \pm 1$ & $12 \pm 1$ & $39 \pm 2$ & $16 \pm 1$ & $10 \pm 1$ & $6 \pm 1$ & $19 \pm 1$ & $7 \pm 1$ & $6 \pm 1$ \\
\hline 21 & $19 \pm 2$ & 0 & $17 \pm 1$ & $28 \pm 1$ & $14 \pm 2$ & $20 \pm 1$ & $24 \pm 1$ & $46 \pm 1$ & $32 \pm 1$ & $10 \pm 2$ & $22 \pm 1$ & $25 \pm 1$ & $4 \pm 1$ & $12 \pm 1$ \\
\hline 22 & $16 \pm 1$ & $10 \pm 1$ & $31 \pm 1$ & $14 \pm 1$ & $7 \pm 1$ & $12 \pm 1$ & $12 \pm 2$ & $39 \pm 1$ & $32 \pm 1$ & $16 \pm 1$ & $16 \pm 1$ & $19 \pm 1$ & $21 \pm 1$ & $12 \pm 1$ \\
\hline 23 & $23 \pm 1$ & $19 \pm 1$ & $21 \pm 1$ & $9 \pm 1$ & $10 \pm 1$ & $16 \pm 1$ & $29 \pm 1$ & $35 \pm 1$ & $16 \pm 1$ & $13 \pm 1$ & $6 \pm 1$ & $31 \pm 1$ & $21 \pm 1$ & $12 \pm 1$ \\
\hline 24 & $19 \pm 1$ & $19 \pm 1$ & $35 \pm 1$ & $12 \pm 1$ & $7 \pm 1$ & $16 \pm 1$ & $18 \pm 1$ & $50 \pm 1$ & $42 \pm 1$ & $3 \pm 1$ & $6 \pm 1$ & $31 \pm 1$ & $27 \pm 2$ & $14 \pm 1$ \\
\hline Chlorothalonil $^{\mathrm{c}}$ & 100 & $69 \pm 1$ & $89 \pm 1$ & 100 & $91 \pm 1$ & $95 \pm 1$ & 100 & $56 \pm 1$ & 100 & 100 & $55 \pm 2$ & 100 & 100 & 100 \\
\hline Carbendazim $^{c}$ & 100 & $53 \pm 1$ & 100 & 100 & 100 & 100 & $71 \pm 1$ & $56 \pm 2$ & $88 \pm 2$ & $83 \pm 1$ & $90 \pm 2$ & 100 & $96 \pm 1$ & 100 \\
\hline
\end{tabular}

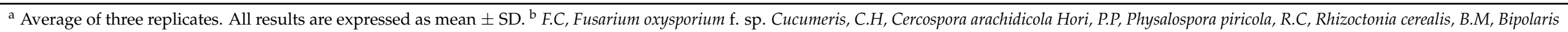

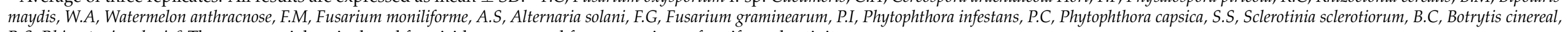
R.S, Rhizoctonia solani. ${ }^{\mathrm{c}}$ The commercial agricultural fungicides were used for comparison of antifungal activity. 
Table 4. In vivo fungicidal activities of compounds 1-24 against six kinds of fungi.

\begin{tabular}{|c|c|c|c|c|c|c|}
\hline \multirow{2}{*}{ Compd. } & \multicolumn{6}{|c|}{ Inhibition Rate ${ }^{a}(\%)$ at $200 \mu \mathrm{g} / \mathrm{mL}$} \\
\hline & $B . G^{\mathbf{b}}$ & $S . S^{\mathbf{b}}$ & B. $C^{\mathbf{b}}$ & $R . S^{\mathbf{b}}$ & C. $C^{\mathbf{b}}$ & $P . C^{b}$ \\
\hline 1-D & 0 & $12 \pm 2$ & $5 \pm 1$ & $9 \pm 2$ & $10 \pm 1$ & $5 \pm 1$ \\
\hline 1-L & 0 & $11 \pm 1$ & $7 \pm 2$ & $7 \pm 1$ & $11 \pm 2$ & $5 \pm 1$ \\
\hline 2-D & 0 & $8 \pm 2$ & $12 \pm 2$ & $8 \pm 2$ & $13 \pm 2$ & $12 \pm 1$ \\
\hline 2-L & 0 & $10 \pm 2$ & $11 \pm 1$ & $7 \pm 2$ & $17 \pm 2$ & $13 \pm 1$ \\
\hline 3 & 0 & $7 \pm 2$ & $13 \pm 1$ & $8 \pm 2$ & $13 \pm 1$ & $13 \pm 1$ \\
\hline 4 & 0 & $10 \pm 1$ & $11 \pm 2$ & 0 & $13 \pm 2$ & 0 \\
\hline 5 & 0 & $19 \pm 3$ & $4 \pm 1$ & $11 \pm 1$ & $5 \pm 1$ & $12 \pm 2$ \\
\hline 6 & 0 & $16 \pm 1$ & $15 \pm 2$ & $8 \pm 2$ & $11 \pm 1$ & $7 \pm 1$ \\
\hline 7 & 0 & $10 \pm 2$ & $12 \pm 1$ & $16 \pm 1$ & $13 \pm 2$ & $5 \pm 1$ \\
\hline 8 & 0 & $4 \pm 1$ & $9 \pm 1$ & 0 & $6 \pm 2$ & $5 \pm 1$ \\
\hline 9 & 0 & $11 \pm 1$ & $5 \pm 1$ & 0 & 0 & 0 \\
\hline 10 & 0 & $11 \pm 3$ & $12 \pm 2$ & $14 \pm 1$ & $10 \pm 1$ & 0 \\
\hline 11 & 0 & $16 \pm 1$ & $1 \pm 1$ & $11 \pm 3$ & $17 \pm 3$ & 0 \\
\hline 12 & 0 & $11 \pm 3$ & $7 \pm 3$ & $20 \pm 1$ & $13 \pm 2$ & $5 \pm 1$ \\
\hline 13 & 0 & $17 \pm 1$ & $6 \pm 1$ & 0 & $13 \pm 2$ & $5 \pm 1$ \\
\hline 14 & 0 & $11 \pm 2$ & $7 \pm 1$ & 0 & $11 \pm 1$ & 0 \\
\hline 15 & 0 & $11 \pm 2$ & $5 \pm 1$ & $11 \pm 2$ & $4 \pm 1$ & 0 \\
\hline 16 & 0 & $19 \pm 1$ & $26 \pm 1$ & $16 \pm 2$ & $13 \pm 1$ & $10 \pm 1$ \\
\hline 17 & 0 & $17 \pm 2$ & $15 \pm 2$ & 0 & 0 & $5 \pm 2$ \\
\hline 18 & 0 & $4 \pm 1$ & $3 \pm 1$ & $20 \pm 1$ & $26 \pm 1$ & $5 \pm 1$ \\
\hline 19 & $20 \pm 2$ & $4 \pm 1$ & $11 \pm 2$ & 0 & $20 \pm 2$ & $10 \pm 2$ \\
\hline 20 & 0 & $17 \pm 2$ & $11 \pm 2$ & 0 & $20 \pm 1$ & 0 \\
\hline 21 & 0 & $7 \pm 1$ & $12 \pm 2$ & 0 & $11 \pm 2$ & $5 \pm 1$ \\
\hline 22 & 0 & $16 \pm 2$ & $15 \pm 2$ & $5 \pm 1$ & $8 \pm 1$ & 0 \\
\hline 23 & 0 & $10 \pm 2$ & $9 \pm 1$ & 0 & $12 \pm 2$ & $5 \pm 1$ \\
\hline 24 & 0 & $11 \pm 1$ & $15 \pm 2$ & 0 & $22 \pm 1$ & 0 \\
\hline azoxystrobin ${ }^{\mathrm{c}}$ & $81 \pm 2$ & 100 & 100 & $75 \pm 2$ & $80 \pm 1$ & $85 \pm 2$ \\
\hline
\end{tabular}

a Average of three replicates. All results are expressed as mean \pm SD. ${ }^{b}$ B.G, Blumeria graminis f.sp. tritici, S.S, Sclerotinia sclerotiorum, B.C, Botrytis cinereal, R.S, Rhizoctonia solani, C.C, Corynespora cassiicola, P.C, Phytophthora capsica. ${ }^{\mathrm{C}}$ The commercial agricultural fungicides were used for comparison of antifungal activity.

\section{Discussion}

\subsection{Synthesis}

Compounds 8-24 bearing a thiazolidine ring based on L-cysteine were synthesized under basic conditions by a one-pot method in high to nearly quantitative yields. The cyclization of aldehydes with cysteine has been reported in the literature under conditions using a water/ethanol mixture $(50: 50, v: v)[7,26]$. To promote the precipitation of the product from the reaction system and improve the yield of the reaction, the amount of ethanol was reduced based on references. The yields of compounds 8-24 ranged from 82\% to $99 \%$. Two nucleophilic attacks of the aldehyde produced the closed ring structure and led to the generation of a new uncontrolled chiral center. Thus, compounds 8-24 are obtained as diastereomeric mixtures [7]. Although the $2 R, 4 R$ and $2 S, 4 R$ isomers were mixed, the distinctive singlet around $5.5 \mathrm{ppm}$ of the hydrogen on $\mathrm{C}-2$ gave a clearly distinguishable ratio of the isomers [7].

\subsection{Phytotoxic Activity}

Healthy growing 5-6 leaf stage tobaccos (Nicotiana tabacum var Xanthi nc) were slected for phytotoxic activity tests. The fresh solutions $(500 \mu \mathrm{g} / \mathrm{mL})$ of compounds 1-24 were gently smeared on the leaves. One hour after treatment, all the treated tobacco leaves were observed intact. The growth of tobacco leaves was continuously observed and calculated the weight after 3, 7, and 10 days, respectively. Encouragingly, none of the compounds were toxic to tobacco leaves. 


\subsection{Structure-Activity Relationship of the Antiviral Activity}

As the results of Table 1, compounds 1-7 had better anti-TMV activities than ribavirin. Chirality has no obvious effect on the antiviral activities of these compounds (inhibitory effect: 1-D $\approx 1$-L, 2-D $\approx 2$-L). Therefore, in the follow-up study, we only used L-cysteine derivatives to explore the effect of different substituents. The antiviral activity was increased slightly when the $\mathrm{S}$ atom and $\mathrm{N}$ atom of cysteine had substituents (antiviral activity: $3>4>7>1,2,5,6)$. Cyclization is an important method to improve molecular stability and biological activity. A series of thiazolidine-4-carboxylic acid-containing compounds 8-24 were designed and synthesized. As shown in Table 1, most of the designed compounds displayed better antiviral activities than ribavirin. For the substituted benzene compounds $8-17$, the electron-withdrawing group substitution at the para position of the benzene ring is beneficial to the improvement of biological activity (inhibitory effect: $11>16>10,17>$ 9 > 8). When introduction of electron-donating groups such as $\mathrm{CH}_{3} \mathrm{O}(\mathbf{1 2}), \mathrm{CH}_{3}(\mathbf{1 3})$ into the para position of the benzene ring, the anti-TMV activity is also improved (inhibitory effect: $13>12>15>8,17>9>8$ ). However, the activity is sharply declined after the introduction of -OH at the para-position of the benzene ring (14). When the 2-position of thiazolidine structure is heterocyclic groups, such as thiophene (18), furan (19), pyridine (20), only compound 20 displayed better anti-TMV activity. Compounds 21-24 with the aliphatic groups at 2-position of thiazolidine exhibited moderate to excellent anti-TMV activities, the introduction of long-chain fat groups (23), and cyclohexyl groups (24) at 2-position of thiazolidine can lead to an increase in activity $(23>24>35>22)$.

Just like the antiviral activity in vitro, compounds $\mathbf{2}-\mathbf{2 4}$ displayed moderate to good in vivo activities (Table 2), and the activities of compounds 3, 4, 7, 13, 23, 24 are significantly higher than that of cysteine. In particular, compound $\mathbf{3}$ showed excellent activity against TMV (inhibitory rate: $51 \%, 47 \%$, and $49 \%$ at $500 \mu \mathrm{g} / \mathrm{mL}$ for inactivation, curative, and protection activity in vivo, respectively). Compounds 4, 7, 10, 13, 20, 23, and 24 displayed higher anti-TMV activities than the commercial plant virucide ribavirin (inhibitory rate: 40,40 , and $38 \%$ at $500 \mu \mathrm{g} / \mathrm{mL}$ for inactivation, curative, and protection activity in vivo, respectively). Compounds 2, 10, 12, 16 exhibited approximate anti-TMV activities as cysteine. The structure-activity relationship revealed that the substitutions of $\mathrm{S}$ atom and $\mathrm{N}$ atom had a great influence on the anti-TMV activity.

\subsection{Study on the Mechanism of Anti-TMV Activity}

\subsubsection{Preliminary Mode of Action}

Considering structural features and biological activity, compound 3 was chosen to study the mechanism of anti-TMV activity. The results showed that 20S CP and TMV RNA could assembled into TMV particles of about $300 \mathrm{~nm}$ in length, and dimethyl sulfoxide (DMSO) had no effect on the assembly (panels A and B of Figure 3). Compound 3 can cause a reduction in the length and number of TMV particles, indicating that it can inhibit the assembly of the viruses (panel $\mathrm{C}$ of Figure 3). The interaction experiment between compound 3 and 20S CP was also designed. The TMV protein can form the homogeneousdispersed disc structure (Figure 4A), and a small amount of DMSO has no effect on the formation (Figure 4B). As seen in Figure 4C, compound 3 can lead to polymerization of TMV CP.

\subsubsection{Molecular Docking Study}

Molecular docking studies were performed to explore the binding sites of cysteine derivatives on TMV CP. Compounds 3, 23, and 24 were selected for molecular docking with TMV CP (PDB code 1EI7). The results showed that compound 3 has lain into the TMV CP activity pocket of SER 255, ASN 73, and GLN 257 (Figure 5A). Compound 3 forms five conventional hydrogen bonds with the active site of SER 255 (1.9 $\AA$ and $2.3 \AA$ ), GLN 257 (2.2 $\AA$ and $2.8 \AA$ ), and ASN $73(2.4 \AA$ ) (Figure 5A). Compound 23 forms three conventional hydrogen bonds with the active site of SER 255 (2.4 $\AA$ ), GLN 257 (1.2 $⿱$ )), and ASN 73 (2.4 (Figure 5B). As seen in Figure 5C, compound 24 forms two conventional hydrogen bonds 
with ASN 73 (2.1 $\AA$ ) and GLY 137 (2.5 $\AA$ ). The molecular docking results indicate that these compounds interact with $\mathrm{CP}$ through hydrogen bonding. The results of molecular docking also showed that compound 3 had more binding sites with TMV CP and shorter hydrogen bond distance. The stronger the interaction with TMV CP, the greater influence on the assembly of TMV, and the higher the inhibition rate. This result is consistent with the activity test.

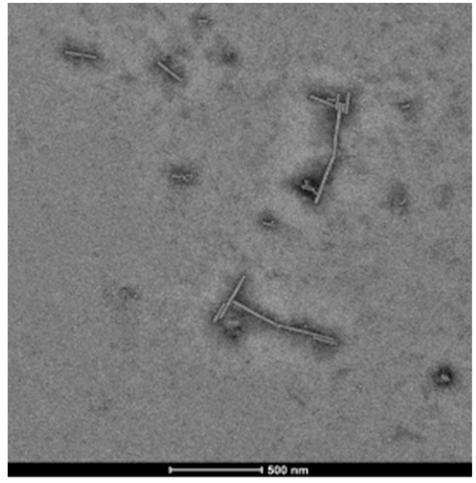

(A)

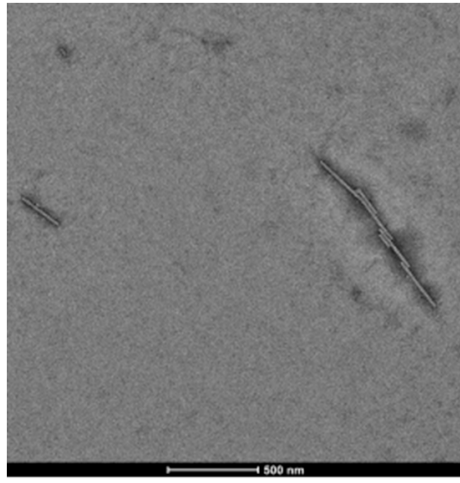

(B)

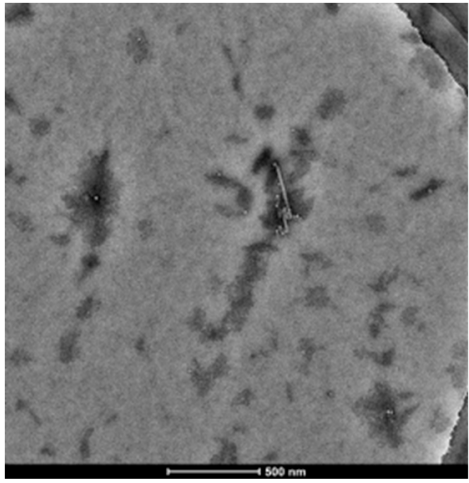

(C)

Figure 3. TMV rod assembly inhibition of compound 3 and NK0209: (A) 20S CP disk + RNA (500 nm scale bar), (B) 20S CP disk + RNA + 1/100 DMSO (500 nm scale bar), (C) 20S CP disk + RNA + $10 \mu \mathrm{M} 3$ (500 nm scale bar).

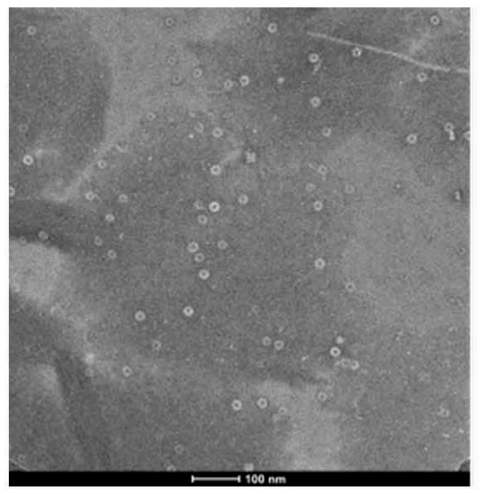

(A)

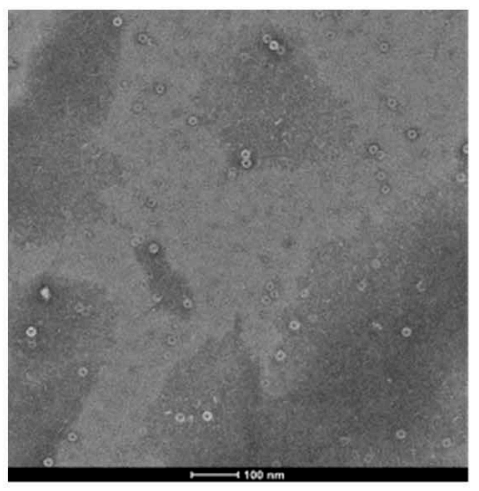

(B)

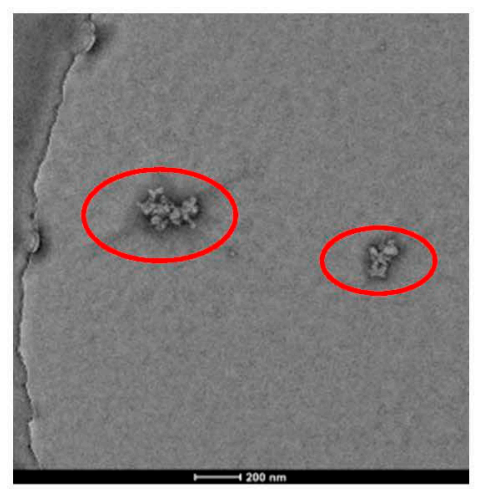

(C)

Figure 4. 20S CP disk assembly inhibition of compound 3 (100 nm scale bar): (A) CP, (B) CP + 1/100 DMSO (100 nm scale bar), (C) CP + $10 \mu \mathrm{M}$ compound 3 (200 nm scale bar).

\subsection{Structure-Activity Relationship of the Fungicidal Activity}

As the results showed in Table 3, all compounds exhibited broad-spectrum fungicidal activities in vitro. Kapachery et al. [30] reported that $N$-acetylcysteine (NAC, compound 7) affected four kinds of bacteria (Aeromonas hydrophila, Pseudomonas putida, Stenotrophomonas sp., and Serratia marcescens) at the concentration of $1.5 \mathrm{mg} / \mathrm{mL}$ which were isolated from polluted reverse osmosis membrane. Perez-Giraldo et al. [31] confirmed that NAC could control bacterial biofilm formation on medical catheters. NAC has been widely used as a mucolytic agent in the treatment of chronic bronchitis [32]. However, the activity of cysteine and its derivatives on plant phytopathogenic fungi was not significant. The inhibitory effect of NAC on 14 plant pathogens was less than $50 \%$. Changing the substituents of N, S, and $\mathrm{O}$ atoms in cysteine can slightly raise its anti-plant pathogen activity. Encouraged by the antifungal activities of compound 16, compounds 1-24 were further evaluated in vivo fungicidal activity. The modification of cysteine had some effect on its fungicidal activity in vivo. It can be seen from the results of fungicidal activity that cysteine and its derivatives have broad-spectrum activity, but with a low to moderate degree of activity. 

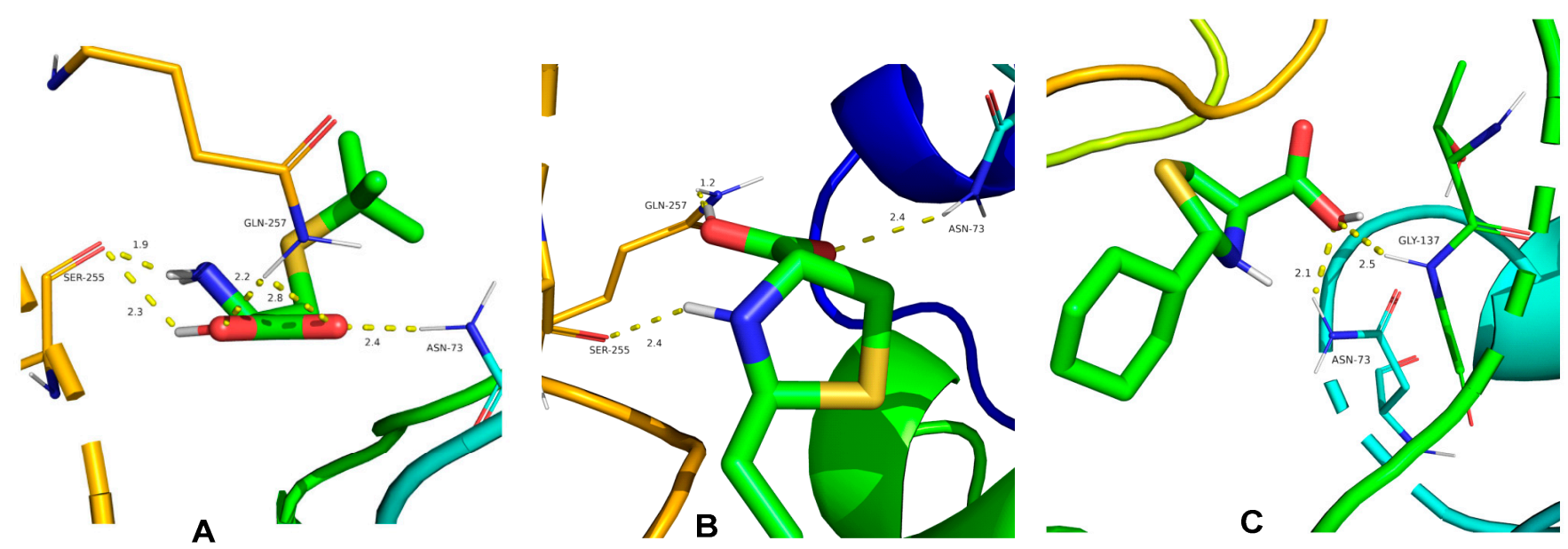

Figure 5. Molecule docking results of (A) compound 3, (B) compound 23, (C) compound 24 with TMV CP.

\section{Materials and Methods}

\subsection{General Procedures}

4.1.1. Instruments

The melting points of the products were determined on an X-4 binocular microscope (Gongyi Yuhua Instrument Co., Gongyi, China) and are not corrected. NMR spectra were acquired with a $400 \mathrm{MHz}\left(100 \mathrm{MHz}\right.$ for $\left.{ }^{13} \mathrm{C}\right)$ instrument (Bruker, Billerica, MA, USA) at room temperature. Chemical shifts were measured relative to residual solvent peaks of DMSO- $d_{6}$ as internal standards $\left({ }^{1} \mathrm{H}: \delta=2.5\right.$ and $\left.3.3 \mathrm{ppm} ;{ }^{13} \mathrm{C}: \delta=39.9 \mathrm{ppm}\right)$. The following abbreviations are used to designate chemical shift multiplicities: $\mathrm{s}=$ singlet, $\mathrm{d}=$ doublet, $\mathrm{dd}=$ doublet of doublets, $\mathrm{t}=$ triplet, $\mathrm{m}=$ multiplet, and brs = broad singlet. HRMS data were recorded with a QFT-ESI instrument (Varian, Palo Alto, CA, USA). All reagents were of analytical reagent (AR) grade or chemically pure (CR). Compounds 1-7 (AR) were purchased from Shanghai Bidepharm Co., Ltd. (Shanghai, China).

\subsubsection{Synthesis of Compounds 8-24}

L-Cysteine ( $3.63 \mathrm{~g}, 30 \mathrm{mmol})$ was dissolved in a mixed solvent of water $(50 \mathrm{~mL})$ and $\mathrm{EtOH}(6 \mathrm{~mL})$. Then the solution of corresponding aldehydes (1.0 equiv.) in EtOH (15 mL) was added. The mixture was stirred at $25^{\circ} \mathrm{C}$ for $6 \mathrm{~h}$, filtered, washed with water, and dried to afford compounds 8-24 [7,26].

(2RS,4R)-2-Phenyl-1,3-thiazolidine-4-carboxylic acid (8). White solid, 93\% yield, m.p. 155-157 ${ }^{\circ} \mathrm{C}$ (lit. [33] 158-159 $\left.{ }^{\circ} \mathrm{C}\right) ;{ }^{1} \mathrm{H}-\mathrm{NMR}$ (DMSO-d $\left.)_{6}\right): 7.25-7.52$ (m, 5H, Ar- $\left.\underline{\mathrm{H}}\right), 5.67$ (s,

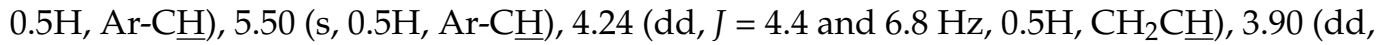
$J=7.6$ and $\left.8.4 \mathrm{~Hz}, 0.5 \mathrm{H}, \mathrm{CH}_{2} \mathrm{C} \underline{\mathrm{H}}\right), 3.38\left(\mathrm{dd}, J=7.2\right.$ and $\left.10.0 \mathrm{~Hz}, 0.5 \mathrm{H}, \mathrm{C}_{2}\right), 3.30(\mathrm{dd}, J=$ 7.2 and $\left.10.4 \mathrm{~Hz}, 0.5 \mathrm{H}, \mathrm{CH}_{2}\right), 3.14\left(\mathrm{dd}, J=4.8\right.$ and $\left.10.4 \mathrm{~Hz}, 0.5 \mathrm{H}, \mathrm{CH}_{2}\right), 3.08(\mathrm{t}, J=8.8 \mathrm{~Hz}$, $\left.0.5 \mathrm{H}, \mathrm{CH}_{2}\right) ;{ }^{13} \mathrm{C}-\mathrm{NMR}\left(\mathrm{DMSO}-d_{6}\right): 172.9,172.2,141.2,138.9,128.5,128.3,127.6,127.2,126.9$, 71.7, 71.1, 65.4, 64.8, 38.4, 37.9; HRMS (ESI) $m / z$ calc'd for $\mathrm{C}_{10} \mathrm{H}_{11} \mathrm{NO}_{2} \mathrm{~S}[\mathrm{M}+\mathrm{H}]^{+}:$209.0510, found 209.0503 .

(2RS,4R)-2-(4-Fluorophenyl)-1,3-thiazolidine-4-carboxylic acid (9). White solid, 82\% yield, m.p. $153-155^{\circ} \mathrm{C}$ (lit. [34] $166{ }^{\circ} \mathrm{C}$ ); ${ }^{1} \mathrm{H}-\mathrm{NMR}$ (DMSO-d $)$ ): 7.48-7.60 (m, 2H, Ar- $\underline{\mathrm{H}}$ ), 7.13-7.22 $(\mathrm{m}, 2 \mathrm{H}, \mathrm{Ar}-\underline{\mathrm{H}}), 5.67(\mathrm{~s}, 0.6 \mathrm{H}, \mathrm{Ar}-\mathrm{C} \underline{\mathrm{H}}), 5.51(\mathrm{~s}, 0.4 \mathrm{H}, \mathrm{Ar}-\mathrm{C} \underline{\mathrm{H}}), 4.21$ (dd, $J=4.8$ and $6.8 \mathrm{~Hz}$, $\left.0.6 \mathrm{H}, \mathrm{CH}_{2} \underline{\mathrm{CH}}\right), 3.89\left(\mathrm{t}, J=7.6 \mathrm{~Hz}, 0.4 \mathrm{H}, \mathrm{CH}_{2} \mathrm{CH}\right), 3.36\left(\mathrm{dd}, J=7.2\right.$ and $\left.10.0 \mathrm{~Hz}, 0.5 \mathrm{H}_{2} \mathrm{CH}_{2}\right)$, $3.30\left(\mathrm{dd}, J=7.2\right.$ and $\left.10.0 \mathrm{~Hz}, 0.7 \mathrm{H}, \mathrm{CH}_{2}\right), 3.13\left(\mathrm{dd}, J=4.4\right.$ and $\left.10.0 \mathrm{~Hz}, 0.6 \mathrm{H}, \mathrm{CH}_{2}\right), 3.09(\mathrm{t}, J$ $\left.=9.2 \mathrm{~Hz}, 0.5 \mathrm{H}, \mathrm{CH}_{2}\right) ;{ }^{13} \mathrm{C}-\mathrm{NMR}\left(\mathrm{DMSO}-d_{6}\right): 173.4,172.6,163.5,163.1,161.1,160.7,138.0$, $135.8,130.0,129.9,129.4,115.8,115.6,115.5,115.3,71.4,70.7,66.0,65.3,38.8,38.4 ;$ HRMS (ESI) $m / z$ calc'd for $\mathrm{C}_{10} \mathrm{H}_{10} \mathrm{FNO}_{2} \mathrm{~S}[\mathrm{M}+\mathrm{H}]^{+}:$227.0416, found 227.0421 . 
(2RS,4R)-2-(4-Bromophenyl)-1,3-thiazolidine-4-carboxylic acid (10). White solid, 87\% yield, m.p. $158-161{ }^{\circ} \mathrm{C}$ (lit. [34] 165-166 ${ }^{\circ} \mathrm{C}$ ); ${ }^{1} \mathrm{H}-\mathrm{NMR}$ (DMSO-d $)$ ): 7.38-7.58 (m, 4H, Ar- $\underline{\mathrm{H}}$ ), 5.67 (s, 0.6H, Ar-C $\underline{\mathrm{H}}), 5.49(\mathrm{~s}, 0.4 \mathrm{H}, \mathrm{Ar}-\mathrm{C} \underline{\mathrm{H}}), 4.17\left(\mathrm{dd}, J=4.8\right.$ and $\left.6.8 \mathrm{~Hz}, 0.6 \mathrm{H}, \mathrm{CH}_{2} \mathrm{C} \underline{\mathrm{H}}\right), 3.90$ $\left(\mathrm{dd}, J=7.2\right.$ and $\left.8.8 \mathrm{~Hz}, 0.4 \mathrm{H}, \mathrm{CH}_{2} \mathrm{C} \underline{\mathrm{H}}\right), 3.35\left(\mathrm{dd}, J=6.8\right.$ and $\left.10.0 \mathrm{~Hz}, 0.6 \mathrm{H}, \mathrm{C}_{2}\right), 3.29(\mathrm{dd}, J$ $=7.2$ and $\left.10.4 \mathrm{~Hz}, 0.7 \mathrm{H}, \mathrm{CH}_{2}\right), 3.12\left(\mathrm{t}, J=5.4 \mathrm{~Hz}, 0.6 \mathrm{H}, \mathrm{CH}_{2}\right), 3.08\left(\mathrm{t}, J=7.2 \mathrm{~Hz}, 0.4 \mathrm{H}, \mathrm{CH}_{2}\right)$; ${ }^{13}$ C-NMR (DMSO- $d_{6}$ ): 173.3, 172.5, 141.6, 139.1, 131.8, 131.6, 130.1, 129.6, 130.0, 71.3, 70.6, 66.0, 65.3, 38.8, 38.5; HRMS (ESI) $m / z$ calc'd for $\mathrm{C}_{10} \mathrm{H}_{10} \mathrm{BrNO}_{2} \mathrm{~S}[\mathrm{M}+\mathrm{H}]^{+}: 288.9616$, found 288.9614 .

(2RS,4R)-2-(4-Trifluoromethylphenyl)-1,3-thiazolidine-4-carboxylic acid (11). White solid, 99\% yield, m.p. $145-147^{\circ} \mathrm{C} ;{ }^{1} \mathrm{H}-\mathrm{NMR}\left(\mathrm{DMSO}-d_{6}\right): 7.63-7.77(\mathrm{~m}, 4 \mathrm{H}, \mathrm{Ar}-\underline{\mathrm{H}}), 5.81(\mathrm{~s}, 0.6 \mathrm{H}$, $\mathrm{Ar}-\mathrm{C} \underline{\mathrm{H}}), 5.61(\mathrm{~s}, 0.4 \mathrm{H}, \mathrm{Ar}-\mathrm{CH}), 4.15\left(\mathrm{t}, J=6.0 \mathrm{~Hz}, 0.6 \mathrm{H}, \mathrm{CH}_{2} \mathrm{CH}\right), 3.95(\mathrm{dd}, J=7.2$ and 8.4 $\mathrm{Hz}, 0.4 \mathrm{H}, \mathrm{CH}_{2} \mathrm{CH}$ ), 3.37 (dd, $J=6.8$ and $\left.10.0 \mathrm{~Hz}, 0.4 \mathrm{H}, \mathrm{CH}_{2}\right), 3.31$ (dd, $J=7.2$ and $10.4 \mathrm{~Hz}$, $\left.0.6 \mathrm{H}, \mathrm{CH}_{2}\right), 3.08-3.12\left(\mathrm{~m}, 1 \mathrm{H}, \mathrm{CH}_{2}\right) ;{ }^{13} \mathrm{C}-\mathrm{NMR}$ (DMSO-d $\left.{ }_{6}\right): 173.2,172.5,147.3,128.7,128.0$, $125.8,125.7,125.6,71.1,70.4,66.1,65.3,38.6,38.5$; HRMS (ESI) $m / z$ calc'd for $\mathrm{C}_{11} \mathrm{H}_{10} \mathrm{~F}_{3} \mathrm{NO}_{2} \mathrm{~S}$ $[\mathrm{M}+\mathrm{H}]^{+}:$277.0384, found 277.0383 .

(2RS,4R)-2-(4-Methoxyphenyl)-1,3-thiazolidine-4-carboxylic acid (12). White solid, 93\% yield, m.p. $153-156{ }^{\circ} \mathrm{C}$ (lit. [33] 163-164 ${ }^{\circ} \mathrm{C}$ ); ${ }^{1} \mathrm{H}-\mathrm{NMR}$ (DMSO- $\left.d_{6}\right): 7.44$ (d, J = 8.8 Hz, $1 \mathrm{H}$, $\operatorname{Ar}-\underline{\mathrm{H}}), 7.37(\mathrm{~d}, J=8.8 \mathrm{~Hz}, 1 \mathrm{H}, \mathrm{Ar}-\underline{\mathrm{H}}), 6.92(\mathrm{~d}, J=8.8 \mathrm{~Hz}, 1 \mathrm{H}, \mathrm{Ar}-\underline{\mathrm{H}}), 6.88(\mathrm{~d}, J=8.4 \mathrm{~Hz}$, $1 \mathrm{H}, \mathrm{Ar}-\underline{\mathrm{H}}), 5.60(\mathrm{~s}, 0.5 \mathrm{H}, \mathrm{Ar}-\mathrm{C} \underline{\mathrm{H}}), 5.45(\mathrm{~s}, 0.5 \mathrm{H}, \mathrm{Ar}-\mathrm{C} \underline{\mathrm{H}}), 4.25(\mathrm{dd}, J=4.0$ and $6.8 \mathrm{~Hz}, 0.5 \mathrm{H}$, $\left.\mathrm{CH}_{2} \mathrm{C} \underline{\mathrm{H}}\right), 3.87\left(\mathrm{dd}, J=7.2\right.$ and $\left.8.8 \mathrm{~Hz}, 0.5 \mathrm{H}, \mathrm{CH}_{2} \mathrm{C} \underline{\mathrm{H}}\right), 3.75\left(\mathrm{~s}, 1.5 \mathrm{H}, \mathrm{C}_{3}\right), 3.74\left(\mathrm{~s}, 1.5 \mathrm{H}, \mathrm{C}_{3}\right)$, $3.36\left(\mathrm{dd}, J=7.2\right.$ and $\left.10.0 \mathrm{~Hz}, 0.5 \mathrm{H}, \mathrm{CH}_{2}\right), 3.28\left(\mathrm{dd}, J=7.2\right.$ and $\left.10.0 \mathrm{~Hz}, 0.5 \mathrm{H}, \mathrm{CH}_{2}\right), 3.15(\mathrm{dd}$, $J=4.0$ and $\left.10.4 \mathrm{~Hz}, 0.5 \mathrm{H}, \mathrm{CH}_{2}\right), 3.07\left(\mathrm{t}, J=8.8 \mathrm{~Hz}, 0.5 \mathrm{H}, \mathrm{CH}_{2}\right) ;{ }^{13} \mathrm{C}-\mathrm{NMR}\left(\mathrm{DMSO}-d_{6}\right): 173.1$, $172.3,159.2,158.7,132.8,130.7,128.5,128.3,114.5,113.8,113.6,71.5,70.9,65.4,64.8,55.1$, 55.0, 38.5, 37.9; HRMS (ESI) $m / z$ calc'd for $\mathrm{C}_{11} \mathrm{H}_{13} \mathrm{NO}_{3} \mathrm{~S}[\mathrm{M}+\mathrm{H}]^{+}:$239.0616, found 239.0612.

(2RS,4R)-2-(4-Methylphenyl)-1,3-thiazolidine-4-carboxylic acid (13). White solid, 99\% yield, m.p. $146-148{ }^{\circ} \mathrm{C}$ (lit. [34] 163.2-163.7 $\left.{ }^{\circ} \mathrm{C}\right) ;{ }^{1} \mathrm{H}-\mathrm{NMR}$ (DMSO-d $)$ ): 7.39 (d, $J=8.0 \mathrm{~Hz}$, $1 \mathrm{H}, \mathrm{Ar}-\underline{\mathrm{H}}), 7.32(\mathrm{~d}, J=8.0 \mathrm{~Hz}, 1 \mathrm{H}, \mathrm{Ar}-\underline{\mathrm{H}}), 7.17(\mathrm{~d}, J=7.6 \mathrm{~Hz}, 1 \mathrm{H}, \mathrm{Ar}-\underline{\mathrm{H}}), 7.13(\mathrm{~d}, J=7.6$ $\mathrm{Hz}, 1 \mathrm{H}, \mathrm{Ar}-\underline{\mathrm{H}}), 5.61(\mathrm{~s}, 0.5 \mathrm{H}, \mathrm{Ar}-\mathrm{C} \underline{\mathrm{H}}), 5.46(\mathrm{~s}, 0.5 \mathrm{H}, \mathrm{Ar}-\mathrm{CH}), 4.24(\mathrm{dd}, J=4.4$ and $6.8 \mathrm{~Hz}$, $\left.0.5 \mathrm{H}, \mathrm{CH}_{2} \mathrm{CH}\right), 3.87\left(\mathrm{dd}, J=7.6\right.$ and $\left.8.8 \mathrm{~Hz}, 0.5 \mathrm{H}, \mathrm{CH}_{2} \mathrm{CH}\right), 3.36(\mathrm{dd}, J=6.8$ and $10.0 \mathrm{~Hz}$, $\left.0.5 \mathrm{H}, \mathrm{CH}_{2}\right), 3.28\left(\mathrm{dd}, J=6.8\right.$ and $\left.10.0 \mathrm{~Hz}, 0.5 \mathrm{H}, \mathrm{CH}_{2}\right), 3.14(\mathrm{dd}, J=4.0$ and $10.0 \mathrm{~Hz}, 0.5 \mathrm{H}$, $\left.\mathrm{CH}_{2}\right), 3.07\left(\mathrm{t}, J=8.8 \mathrm{~Hz}, 0.5 \mathrm{H}, \underline{\mathrm{CH}}_{2}\right), 2.30\left(\mathrm{~s}, 1.5 \overline{\mathrm{H}}_{1} \mathrm{CH}_{3}\right), 2.28\left(\mathrm{~s}, 1.5 \mathrm{H}, \mathrm{C}_{3}\right) ;{ }^{13} \mathrm{C}-\mathrm{NMR}$ (DMSO- $d_{6}$ ): 173.5, 172.8, 138.5, 138.1, 137.3, 136.3, 130.2, 130.1, 129.4, 129.2, 127.6, 127.4, 72.2, 71.6, 65.9, 65.3, 38.9, 38.4, 21.2, 21.1; HRMS (ESI) $m / z$ calc'd for $\mathrm{C}_{11} \mathrm{H}_{13} \mathrm{NO}_{2} \mathrm{~S}[\mathrm{M}+\mathrm{H}]^{+}$: 223.0667, found 223.0673 .

(2RS,4R)-2-(4-Hydroxyphenyl)-1,3-thiazolidine-4-carboxylic acid (14). White solid, 81\% yield, m.p. $161-164{ }^{\circ} \mathrm{C}$ (lit. [35] 167-1169 ${ }^{\circ} \mathrm{C}$ ); ${ }^{1} \mathrm{H}-\mathrm{NMR}$ (DMSO-d 6 ): 9.51 (br s, 1H, OH $)$, $7.33(\mathrm{~d}, J=8.8 \mathrm{~Hz}, 1 \mathrm{H}, \mathrm{Ar}-\underline{\mathrm{H}}), 7.26(\mathrm{~d}, J=8.0 \mathrm{~Hz}, 1 \mathrm{H}, \mathrm{Ar}-\underline{\mathrm{H}}), 6.75(\mathrm{~d}, J=8.0 \mathrm{~Hz}, 1 \mathrm{H}, \mathrm{Ar}-\underline{\mathrm{H}})$, $6.72(\mathrm{~d}, J=8.8 \mathrm{~Hz}, 1 \mathrm{H}, \mathrm{Ar}-\underline{\mathrm{H}}), 5.55(\mathrm{~s}, 0.5 \mathrm{H}, \mathrm{Ar}-\mathrm{CH}), 5.41(\mathrm{~s}, 0.5 \mathrm{H}, \mathrm{Ar}-\mathrm{CH}), 4.26(\mathrm{dd}, J=3.6$ and $\left.6.8 \mathrm{~Hz}, 0.5 \mathrm{H}, \mathrm{CH}_{2} \mathrm{C} \underline{\mathrm{H}}\right), 3.86\left(\mathrm{t}, J=7.6 \mathrm{~Hz}, 0.5 \mathrm{H}, \mathrm{CH}_{2} \mathrm{C} \underline{\mathrm{H}}\right), 3.36(\mathrm{dd}, J=6.8$ and $10.0 \mathrm{~Hz}$, $\left.0.5 \mathrm{H}, \mathrm{CH}_{2}\right), 3.28\left(\mathrm{dd}, J=6.8\right.$ and $\left.10.0 \mathrm{~Hz}, 0.5 \mathrm{H}, \mathrm{CH}_{2}\right), 3.16(\mathrm{dd}, J=3.6$ and $10.4 \mathrm{~Hz}, 0.5 \mathrm{H}$, $\left.\mathrm{CH}_{2}\right), 3.06\left(\mathrm{t}, J=9.2 \mathrm{~Hz}, 0.5 \mathrm{H}, \mathrm{CH}_{2}\right) ;{ }^{13} \mathrm{C}-\mathrm{NMR}$ (DMSO- $\left.d_{6}\right): 173.1,172.3,157.4,156.9,130.7$, $128.8,128.5,128.3,115.1,114.9,71.8,71.2,65.2,64.7,38.5,37.8$; HRMS (ESI) $m / z$ calc'd for $\mathrm{C}_{10} \mathrm{H}_{11} \mathrm{NO}_{3} \mathrm{~S}[\mathrm{M}+\mathrm{H}]^{+}: 225.0460$, found 225.0463 .

(2RS,4R)-2-(3-Hydroxy-4-methoxyphenyl)-1,3-thiazolidine-4-carboxylic acid (15). White solid, 93\% yield, m.p. 170-173 ${ }^{\circ} \mathrm{C} ;{ }^{1} \mathrm{H}-\mathrm{NMR}$ (DMSO- $\left.d_{6}\right)$ : 9.03 (br s, 1H, O $\underline{\mathrm{H}}$ ), 7.12 (s, 0.5H, Ar- $\underline{\mathrm{H}}), 7.11$ (s, 0.5H, Ar- $\underline{\mathrm{H}}), 6.83-6.90$ (m, 1H, Ar- $\underline{\mathrm{H}}), 6.69-6.74$ (m, 1H, Ar- $\underline{\mathrm{H}}), 5.53$ (s, 0.5H, $\mathrm{Ar}-\mathrm{C} \underline{\mathrm{H}}), 5.40(\mathrm{~s}, 0.5 \mathrm{H}, \hat{\mathrm{Ar}}-\mathrm{C} \underline{\mathrm{H}}), 4.29\left(\mathrm{dd}, J=3.6\right.$ and $\left.6.8 \mathrm{~Hz}, 0.5 \mathrm{H}, \mathrm{CH}_{2} \mathrm{C} \underline{\mathrm{H}}\right), 3.83(\mathrm{dd}, J=$ 7.2 and $\left.8.8 \mathrm{~Hz}, 0.5 \mathrm{H}, \mathrm{CH}_{2} \mathrm{CH}\right), 3.77(\mathrm{~s}, 1.5 \mathrm{H}), 3.76\left(\mathrm{~s}, 0.5 \mathrm{H}, \mathrm{CH}_{2} \mathrm{CH}\right), 3.33(\mathrm{dd}, J=7.2$ and $\left.10.0 \mathrm{~Hz}, 0.5 \mathrm{H}, \mathrm{CH}_{2}\right), 3.28\left(\mathrm{dd}, J=7.2\right.$ and $\left.10.0 \mathrm{~Hz}, 0.5 \mathrm{H}, \mathrm{CH}_{2}\right), 3.16(\mathrm{dd}, J=3.6$ and $10.4 \mathrm{~Hz}$, $\left.0.5 \mathrm{H}, \mathrm{CH}_{2}\right), 3.06\left(\mathrm{t}, J=9.2 \mathrm{~Hz}, 0.5 \mathrm{H}, \mathrm{CH}_{2}\right) ;{ }^{13} \mathrm{C}-\mathrm{NMR}\left(\mathrm{DMSO}-d_{6}\right): 173.7,172.8,148.0,147.8$, 147.1, 146.6, 131.7, 129.9, 120.4, 120.1, 115.6, 115.4, 111.9, 111.7, 72.6, 72.0, 66.0, 65.3, 56.1, 56.0, 38.9, 38.3; HRMS (ESI) $m / z$ calc'd for $\mathrm{C}_{11} \mathrm{H}_{13} \mathrm{NO}_{4} \mathrm{~S}[\mathrm{M}+\mathrm{H}]^{+}:$255.0565, found 255.0573. 
(2RS,4R)-2-(4-Nitrophenyl)-1,3-thiazolidine-4-carboxylic acid (16). White solid, 99\% yield, m.p. 94-97 ${ }^{\circ} \mathrm{C}$ (lit. [34] 95-97 ${ }^{\circ} \mathrm{C}$ ); ${ }^{1} \mathrm{H}-\mathrm{NMR}$ (DMSO-d 6 ): 8.17-8.23 (m, 2H, Ar- $\underline{\mathrm{H}}$ ), 7.80 (d, J $=8.8 \mathrm{~Hz}, 0.8 \mathrm{H}, \mathrm{Ar}-\underline{\mathrm{H}}), 7.67(\mathrm{~d}, J=8.8 \mathrm{~Hz}, 1 \mathrm{H}, \mathrm{Ar}-\underline{\mathrm{H}}), 5.87(\mathrm{~s}, 0.6 \mathrm{H}, \mathrm{Ar}-\mathrm{C} \underline{\mathrm{H}}), 5.66(\mathrm{~s}, 0.4 \mathrm{H}$, $\operatorname{Ar}-\underline{\mathrm{H}}_{\text {) }}, 4.12\left(\mathrm{t}, \mathrm{J}=6.4 \mathrm{~Hz}, 0.7 \mathrm{H}, \mathrm{CH}_{2} \mathrm{C} \underline{\mathrm{H}}\right), 3.97\left(\mathrm{dd}, J=6.8\right.$ and $\left.9.2 \mathrm{~Hz}, 0.5 \mathrm{H}, \mathrm{CH}_{2} \mathrm{C} \underline{\mathrm{H}}\right), 3.37$ $\left(\mathrm{dd}, J=6.8\right.$ and $\left.10.0 \mathrm{~Hz}, 0.7 \mathrm{H}, \mathrm{CH}_{2}\right), 3.32\left(\mathrm{dd}, J=6.8\right.$ and $\left.10.0 \mathrm{~Hz}, 0.8 \mathrm{H}, \mathrm{CH}_{2}\right), 3.06-3.13(\mathrm{~m}$, $\left.1 \mathrm{H}, \mathrm{CH}_{2}\right) ;{ }^{13} \mathrm{C}-\mathrm{NMR}\left(\mathrm{DMSO}-d_{6}\right): 173.1,172.5,150.6,147.7,147.1,129.1,128.3,124.0123 .9$, 70.6, 69.9, 66.2, 65.4, 38.6, 38.5; HRMS (ESI) $m / z$ calc'd for $\mathrm{C}_{10} \mathrm{H}_{10} \mathrm{~N}_{2} \mathrm{O}_{4} \mathrm{~S}[\mathrm{M}+\mathrm{H}]^{+}: 254.0361$, found 254.0367 .

(2RS,4R)-2-(3-Nitrophenyl)-1,3-thiazolidine-4-carboxylic acid (17). White solid, 99\% yield, m.p. $90-93{ }^{\circ} \mathrm{C} ;{ }^{1} \mathrm{H}-\mathrm{NMR}$ (DMSO- $d_{6}$ ): 8.46 (s, 0.4H, Ar- $\left.\underline{\mathrm{H}}\right), 8.29$ (s, 0.6H, Ar- $\underline{\mathrm{H}}$ ), 8.17 (dd, $J=$ 1.6 and $8.0 \mathrm{~Hz}, 0.4 \mathrm{H}, \mathrm{Ar}-\underline{\mathrm{H}}), 8.12(\mathrm{dd}, J=1.6$ and $8.4 \mathrm{~Hz}, 0.6 \mathrm{H}, \mathrm{Ar}-\underline{\mathrm{H}}), 7.96(\mathrm{~d}, J=8.0 \mathrm{~Hz}$, $0.4 \mathrm{H}, \mathrm{Ar}-\underline{\mathrm{H}}), 7.87(\mathrm{~d}, J=7.6 \mathrm{~Hz}, 0.6 \mathrm{H}, \mathrm{Ar}-\underline{\mathrm{H}}), 7.60-7.67(\mathrm{~m}, 1 \mathrm{H}, \mathrm{Ar}-\underline{\mathrm{H}}), 5.86(\mathrm{~s}, 0.6 \mathrm{H}, \mathrm{Ar}-\mathrm{C} \underline{\mathrm{H}})$, $5.67(\mathrm{~s}, 0.4 \mathrm{H}, \mathrm{Ar}-\mathrm{CH}), 4.14(\mathrm{t}, J=6.0 \mathrm{~Hz}, 0.6 \mathrm{H}), 3.95\left(\mathrm{dd}, J=7.2\right.$ and $\left.8.4 \mathrm{~Hz}, 0.5 \mathrm{H}, \mathrm{CH}_{2} \mathrm{CH}\right)$, 3.31-3.38 (m, 1H, $\left.\underline{\mathrm{CH}}_{2}\right), 3.09-3.15\left(\mathrm{~m}, 1 \mathrm{H}, \mathrm{CH}_{2}\right) ;{ }^{13} \mathrm{C}-\mathrm{NMR}$ (DMSO-d $)$ ): 173.1, 172.4, 148.2, 148.1, 145.1, 142.5, 134.8, 134.3, 130.4, 130.3, 70.6, 69.9, 66.3, 65.2, 38.6, 38.5; HRMS (ESI) $\mathrm{m} / \mathrm{z}$ calc'd for $\mathrm{C}_{10} \mathrm{H}_{10} \mathrm{~N}_{2} \mathrm{O}_{4} \mathrm{~S}[\mathrm{M}+\mathrm{H}]^{+}$: 254.0361, found 254.0365.

(2RS,4R)-2-(Thiophen-2-yl)thiazolidine-4-carboxylic acid (18). White solid, 99\% yield, m.p. 144-147 ${ }^{\circ} \mathrm{C}$ (lit. [36] 146-147 $\left.{ }^{\circ} \mathrm{C}\right) ;{ }^{1} \mathrm{H}-\mathrm{NMR}$ (DMSO-d 6 ): 7.51 (dd, $J=0.8$ and $4.8 \mathrm{~Hz}, 0.3 \mathrm{H}$, Ar- $\underline{\mathrm{H}}), 7.42(\mathrm{dd}, J=0.8$ and $5.2 \mathrm{~Hz}, 0.6 \mathrm{H}, \mathrm{Ar}-\underline{\mathrm{H}}), 7.20(\mathrm{~d}, J=3.2 \mathrm{~Hz}, 0.4 \mathrm{H}, \mathrm{Ar}-\underline{\mathrm{H}}), 7.06(\mathrm{~d}, J=$ $3.6 \mathrm{~Hz}, 0.6 \mathrm{H}, \mathrm{Ar}-\underline{\mathrm{H}}), 6.99(\mathrm{dd}, J=3.2$ and $4.8 \mathrm{~Hz}, 0.3 \mathrm{H}, \mathrm{Ar}-\underline{\mathrm{H}}), 6.95(\mathrm{dd}, J=3.6$ and $4.2 \mathrm{~Hz}$, 0.6H, Ar- $\underline{\mathrm{H}}), 5.94(\mathrm{~s}, 0.7 \mathrm{H}, \mathrm{Ar}-\mathrm{CH}), 5.75(\mathrm{~s}, 0.4 \mathrm{H}, \mathrm{Ar}-\mathrm{CH}), 4.07\left(\mathrm{t}, J=6.4 \mathrm{~Hz}, 0.7 \mathrm{H}, \mathrm{CH}_{2} \mathrm{CH}\right)$, $3.91\left(\mathrm{dd}, J=7.2\right.$ and $\left.8.8 \mathrm{~Hz}, 0.4 \mathrm{H}, \mathrm{CH}_{2} \mathrm{CH}\right), 3.31-3.39\left(\mathrm{~m}, 1 \mathrm{H}, \mathrm{CH}_{2}\right), 3.03-3.11\left(\mathrm{~m}, 1 \mathrm{H}, \mathrm{CH}_{2}\right)$; ${ }^{13}$ C-NMR (DMSO- $d_{6}$ ): 172.6, 172.2, 147.1, 142.8, 126.8, 126.7, 126.2, 125.4, 125.2, 66.6, 66.1, 65.4, 64.5, 38.5, 38.0; HRMS (ESI) $m / z$ calc'd for $\mathrm{C}_{8} \mathrm{H}_{9} \mathrm{NO}_{2} \mathrm{~S}_{2}[\mathrm{M}+\mathrm{H}]^{+}:$215.0075, found 215.0079 .

(2RS,4R)-2-(Furan-2-yl)thiazolidine-4-carboxylic acid (19). White solid, 99\% yield, m.p. 137-140 ${ }^{\circ} \mathrm{C}$ (lit. [33] 137-138 ${ }^{\circ} \mathrm{C}$ ); ${ }^{1} \mathrm{H}-\mathrm{NMR}$ (DMSO-d 6 ): 7.65-7.66 (m, 0.3H, Ar$(\mathrm{m}, 0.6 \mathrm{H}, \mathrm{Ar}-\underline{\mathrm{H}}), 6.50(\mathrm{~d}, J=3.2 \mathrm{~Hz}, 0.3 \mathrm{H}, \mathrm{Ar}-\underline{\mathrm{H}}), 6.43-6.44(\mathrm{~m}, 0.3 \mathrm{H}, \mathrm{Ar}-\underline{\mathrm{H}}), 6.37-6.38(\mathrm{~m}$,

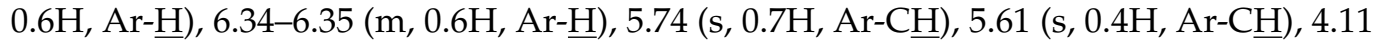
$\left(\mathrm{t}, J=6.4 \mathrm{~Hz}, 0.7 \mathrm{H}, \mathrm{CH}_{2} \mathrm{CH}\right), 3.87\left(\mathrm{dd}, J=6.8\right.$ and $\left.8.8 \mathrm{~Hz}, 0.4 \mathrm{H}, \mathrm{CH}_{2} \mathrm{CH}\right), 3.27-3.37(\mathrm{~m}$, $\left.1 \mathrm{H}, \mathrm{CH}_{2}\right), 2.97-3.01\left(\mathrm{~m}, 1 \mathrm{H}, \mathrm{CH}_{2}\right) ;{ }^{13} \mathrm{C}-\mathrm{NMR}$ (DMSO-d $\left.{ }_{6}\right): 173.0,172.7,154.9,151.8,143.4$, $142.9,111.1,110.8,108.0,106.8,65.9,65.3,64.7,64.4,38.6,38.3 ;$ HRMS (ESI) $m / z$ calc'd for $\mathrm{C}_{8} \mathrm{H}_{9} \mathrm{NO}_{3} \mathrm{~S}[\mathrm{M}+\mathrm{H}]^{+}:$119.0303, found 119.0305 .

(2RS,4R)-2-(Pyridin-4-yl)thiazolidine-4-carboxylic acid (20). White solid, 93\% yield, m.p. 163-165 ${ }^{\circ} \mathrm{C}$ (lit. [34] 175-176 ${ }^{\circ} \mathrm{C}$ ); ${ }^{1} \mathrm{H}-\mathrm{NMR}$ (DMSO- $d_{6}$ ): 8.55 (d, $J=6.0 \mathrm{~Hz}, 0.4 \mathrm{H}, \mathrm{Ar}-\underline{\mathrm{H}}$ ), 8.50 $(\mathrm{d}, J=6.1 \mathrm{~Hz}, 1.6 \mathrm{H}, \mathrm{Ar}-\underline{\mathrm{H}}), 7.52(\mathrm{~d}, J=6.0 \mathrm{~Hz}, 0.4 \mathrm{H}, \mathrm{Ar}-\underline{\mathrm{H}}), 7.40(\mathrm{~d}, J=6.0 \mathrm{~Hz}, 1.6 \mathrm{H}, \mathrm{Ar}-\underline{\mathrm{H}})$, $5.75(\mathrm{~s}, 0.8 \mathrm{H}, \mathrm{Ar}-\mathrm{C} \underline{\mathrm{H}}), 5.54(\mathrm{~s}, 0.2 \mathrm{H}, \mathrm{Ar}-\mathrm{C} \underline{\mathrm{H}}), 4.10\left(\mathrm{t}, \mathrm{J}=6.3 \mathrm{~Hz}, 0.8 \mathrm{H}, \mathrm{CH}_{2} \mathrm{C} \underline{\mathrm{H}}\right), 3.97(\mathrm{dd}, J=$ 6.9 and $\left.8.8 \mathrm{~Hz}, 0.2 \mathrm{H}, \mathrm{CH}_{2} \mathrm{CH}\right), 3.36\left(\mathrm{dd}, J=6.9\right.$ and $\left.10.0 \mathrm{~Hz}, 0.2 \mathrm{H}, \mathrm{CH}_{2}\right), 3.30(\mathrm{dd}, J=6.8$ and $\left.10.2 \mathrm{~Hz}, 0.8 \mathrm{H}, \underline{\mathrm{CH}}_{2}\right), 3.04-3.10\left(\mathrm{~m}, 1 \mathrm{H}, \underline{\mathrm{CH}}_{2}\right) ;{ }^{13} \mathrm{C}-\mathrm{NMR}$ (DMSO- $\left.d_{6}\right): 173.0,172.5,151.9$, 151.1, 150.1, 149.8, 122.3, 122.1, 70.2, 69.5, 66.2, 65.3, 38.6, 38.4; HRMS (ESI) $\mathrm{m} / \mathrm{z}$ calc'd for $\mathrm{C}_{9} \mathrm{H}_{10} \mathrm{~N}_{2} \mathrm{O}_{2} \mathrm{~S}[\mathrm{M}+\mathrm{H}]^{+}:$210.0463, found 210.0460 .

(2RS,4R)-2-Benzylthiazolidine-4-carboxylic acid (21). White solid, 93\% yield, m.p. 152$155{ }^{\circ} \mathrm{C}$ (lit. [35] 165-166 $\left.{ }^{\circ} \mathrm{C}\right) ;{ }^{1} \mathrm{H}-\mathrm{NMR}$ (DMSO-d $)$ ): 7.18-7.30 (m, 5H, Ar- $\left.\underline{\mathrm{H}}\right), 4.81$ (t, J = 7.0 $\mathrm{Hz}, 0.7 \mathrm{H}, \mathrm{SC} \underline{\mathrm{H}}), 4.65(\mathrm{t}, J=6.8 \mathrm{~Hz}, 0.3 \mathrm{H}, \mathrm{SCH}), 4.15\left(\mathrm{dd}, J=5.6\right.$ and $\left.6.7 \mathrm{~Hz}, 0.7 \mathrm{H}, \mathrm{CH}_{2} \mathrm{CH}\right)$, $3.72\left(\mathrm{dd}, J=6.9\right.$ and $\left.9.2 \mathrm{~Hz}, 0.3 \mathrm{H}, \mathrm{CH}_{2} \mathrm{C} \underline{\mathrm{H}}\right), 3.07-3.27\left(\mathrm{~m}, 2 \mathrm{H}, \mathrm{CH}_{2} \mathrm{C} \underline{\mathrm{H}}\right.$ and $\left.\mathrm{Ar}-\mathrm{CH}_{2}\right), 3.00$ $\left(\mathrm{dd}, J=7.3\right.$ and $\left.13.7 \mathrm{~Hz}, 0.3 \mathrm{H}, \mathrm{CH}_{2} \mathrm{C} \underline{\mathrm{H}}\right), 2.92\left(\mathrm{dd}, J=5.4\right.$ and $10.2 \mathrm{~Hz}, 0.7 \mathrm{H}, \overline{\mathrm{CH}}_{2} \mathrm{CH}$ ), 2.75-2.85 (m, 1H, Ar-CH $)$; ${ }^{13}$ C-NMR (DMSO-d $): 173.3,172.7,139.5,139.3,129.6,129.4$, 128.7, 128.6, 126.9, 126.7, 72.4, 71.8, 65.7, 64.6, 43.3, 41.1, 37.8, 37.6; HRMS (ESI) m/z calc'd for $\mathrm{C}_{11} \mathrm{H}_{13} \mathrm{NO}_{2} \mathrm{~S}[\mathrm{M}+\mathrm{H}]^{+}:$223.0667, found 223.0662 .

(2RS,4R)-2-Propylthiazolidine-4-carboxylic acid (22). White solid, 93\% yield, m.p. 190$192{ }^{\circ} \mathrm{C} ;{ }^{1} \mathrm{H}-\mathrm{NMR}$ (DMSO- $\left.d_{6}\right): 4.56(\mathrm{t}, J=6.6 \mathrm{~Hz}, 0.5 \mathrm{H}, \mathrm{SC} \underline{\mathrm{H}}), 4.42(\mathrm{t}, J=7.2 \mathrm{~Hz}, 0.5 \mathrm{H}, \mathrm{SC} \underline{\mathrm{H}})$, $4.07\left(\mathrm{dd}, J=6.7 \mathrm{~Hz}\right.$ and $\left.5.4 \mathrm{~Hz}, 0.5 \mathrm{H}, \mathrm{SCH}_{2} \mathrm{CH}\right), 3.71\left(\mathrm{dd}, J=7.0\right.$ and $\left.9.0 \mathrm{~Hz}, 0.5 \mathrm{H}, \mathrm{SCH}_{2} \mathrm{C} \underline{\mathrm{H}}\right)$, $3.20\left(\mathrm{dd}, J=7.0\right.$ and $\left.9.9 \mathrm{~Hz}, 0.5 \mathrm{H}, \mathrm{SCH}_{2}\right), 3.09\left(\mathrm{dd}, J=7.0\right.$ and $\left.10.2 \mathrm{~Hz}, 0.5 \mathrm{H}, \mathrm{SC}_{2}\right), 2.94$ 
$\left(\mathrm{dd}, J=5.1\right.$ and $\left.10.2 \mathrm{~Hz}, 0.5 \mathrm{H}, \mathrm{SCH}_{2}\right), 2.76\left(\mathrm{t}, J=9.4 \mathrm{~Hz}, 0.5 \mathrm{H}, \mathrm{SCH}_{2}\right), 1.85-1.93(\mathrm{~m}, 0.5 \mathrm{H}$, $\left.\mathrm{CH}_{2} \mathrm{CH}_{2} \mathrm{CH}\right), 1.65-1.77\left(\mathrm{~m}, 1 \mathrm{H}, \mathrm{CH}_{2} \mathrm{CH}_{2} \mathrm{CH}\right), 1.49-1.56\left(\mathrm{~m}, 0.5 \mathrm{H}, \mathrm{CH}_{2} \mathrm{C}_{2} \mathrm{CH}\right), 1.35-1.43$ $\left(\mathrm{m}, 2 \mathrm{H}, \mathrm{CH}_{2} \mathrm{CH}_{2}\right), 0.86-0.91\left(\mathrm{~m}, 3 \mathrm{H}, \mathrm{CH}_{3}\right) ;{ }^{13} \mathrm{C}-\mathrm{NMR}$ (DMSO- $\left.d_{6}\right): 173.3,172.8,71.2,70.4$, 65.6, 64.6, 39.3, 39.2, 37.4, 37.0, 21.4, 21.1, 14.3, 14.2; HRMS (ESI) $\mathrm{m} / z$ calc'd for $\mathrm{C}_{7} \mathrm{H}_{13} \mathrm{NO}_{2} \mathrm{~S}$ $[\mathrm{M}+\mathrm{H}]^{+}: 175.0667$, found 175.0670 .

(2RS,4R)-2-Heptylthiazolidine-4-carboxylic acid (23). White solid, 93\% yield, m.p. 136$139{ }^{\circ} \mathrm{C}$ (lit. [37] 159-160 ${ }^{\circ} \mathrm{C}$ ); ${ }^{1} \mathrm{H}-\mathrm{NMR}$ (DMSO- $\left.d_{6}\right): 4.54(\mathrm{t}, J=6.6 \mathrm{~Hz}, 0.5 \mathrm{H}, \mathrm{SC} \underline{\mathrm{H}}), 4.40(\mathrm{t}, J=$ $6.7 \mathrm{~Hz}, 0.5 \mathrm{H}, \mathrm{SCH}), 4.06\left(\mathrm{t}, J=6.1 \mathrm{~Hz}, 0.5 \mathrm{H}, \mathrm{SCH}_{2} \mathrm{CH}\right), 3.70\left(\mathrm{t}, J=8.5 \mathrm{~Hz}, 0.5 \mathrm{H}, \mathrm{SCH}_{2} \mathrm{CH}\right)$, $3.19\left(\mathrm{t}, J=9.6 \mathrm{~Hz}, 0.5 \mathrm{H}, \mathrm{SCH}_{2}\right), 3.08\left(\mathrm{t}, J=9.8 \mathrm{~Hz}, 0.5 \mathrm{H}, \mathrm{SCH}_{2}\right), 2.93(\mathrm{dd}, J=4.9$ and $9.8 \mathrm{~Hz}$, $\left.0.5 \mathrm{H}, \mathrm{SCH}_{2}\right), 2.75\left(\mathrm{t}, J=9.6 \mathrm{~Hz}, 0.5 \mathrm{H}, \mathrm{SC}_{2}\right), 1.85-1.92\left(\mathrm{~m}, 0.5 \mathrm{H}, \mathrm{CH}_{2} \mathrm{CH}_{2} \mathrm{CH}\right), 1.69-1.76(\mathrm{~m}$, $\left.1 \mathrm{H}, \mathrm{CH}_{2} \mathrm{CH}_{2} \mathrm{CH}\right), 1.50-1.67$ (m, 0.5H, $\left.\mathrm{CH}_{2} \mathrm{CH}_{2} \mathrm{CH}\right), 1.24-1.48$ (m, 10H, $\left.\mathrm{CH}_{2} \mathrm{CH}_{2}\right), 0.84-0.86$ $\left(\mathrm{m}, 3 \mathrm{H}, \mathrm{CH}_{3}\right) ;{ }^{13} \mathrm{C}-\mathrm{NMR}$ (DMSO- $\left.d_{6}\right): 173.3,172.8,71.5,70.8,65.7,64.6,37.4,37.1,37.0,35.3$, 31.7, 29.3, 29.2, 29.1, 29.0, 28.1, 27.9, 22.5, 14.4; HRMS (ESI) $m / z$ calc'd for $\mathrm{C}_{11} \mathrm{H}_{21} \mathrm{NO}_{2} \mathrm{~S}[\mathrm{M}+$ $\mathrm{H}]^{+}:$231.1293, found 231.1294.

(2RS,4R)-2-Cyclohexylthiazolidine-4-carboxylic acid (24). White solid, 82\% yield, m.p.184$187^{\circ} \mathrm{C} ;{ }^{1} \mathrm{H}-\mathrm{NMR}$ (DMSO- $\left.d_{6}\right)$ : 4.01-4.02 (m, 0.4H, SCH $), 3.65-3.69$ (m, 0.6H, SCH), 3.13-3.16 (m, 0.6H, SCH$\left.{ }_{2} \mathrm{CH}\right), 2.98-3.01\left(\mathrm{~m}, 0.4 \mathrm{H}, \mathrm{SCH}_{2} \mathrm{CH}\right), 2.87-2.89\left(\mathrm{~m}, 0.4 \mathrm{H}, \mathrm{SCH}_{2} \mathrm{CH}\right), 2.65-2.68$ (m, 0.6H, SC $\left.\underline{\mathrm{H}}_{2} \mathrm{CH}\right), 1.95-1.97\left(\mathrm{~m}, 1 \mathrm{H}, \mathrm{CH}_{2} \mathrm{CHCH}_{2}\right), 1.40-1.66\left(\mathrm{~m}, 4 \mathrm{H}, \mathrm{CH}_{2} \mathrm{CH}_{2} \mathrm{CH}\right), 0.98$ $1.15\left(\mathrm{~m}, 6 \mathrm{H}, \mathrm{CH}_{2} \mathrm{CH}_{2} \mathrm{CH}_{2}\right.$ ); ${ }^{13} \mathrm{C}-\mathrm{NMR}$ (DMSO- $d_{6}$ ): 173.4, 172.9, 77.4, 76.6, 65.7, 64.8, 44.1, $43.1,36.7,31.7,31.6,30.1,26.4,26.0,25.9,25.8$; HRMS (ESI) $m / z$ calc'd for $\mathrm{C}_{10} \mathrm{H}_{17} \mathrm{NO}_{2} \mathrm{~S}[\mathrm{M}+$ $\mathrm{H}]^{+}:$215.0980, found 215.0978 .

\subsection{Biological Assays}

Each test was repeated three times at $25 \pm 1^{\circ} \mathrm{C}$. Active effect expressed in percentage scale of 0-100 (0: no activity; 100: total inhibited). Specific test methods for the anti-TMV and fungicidal activities were carried out by the literature method [5,27], Detailed bioassay procedures for the anti-TMV and fungicidal activities were described in the literature and can be seen in the Supplementary Materials.

\section{Conclusions}

Based on the structure of natural product cysteine, a series of cysteine and its derivatives were designed, synthesized, and evaluated for their antiviral and antifungal activities in vitro and in vivo. By studying the influence of $\mathrm{O}, \mathrm{N}$, and $\mathrm{S}$ atom substituents of cysteine, it was found that some compounds had excellent anti-TMV activity. The preliminary mode of action studies exhibited that compound 3 can hold back virus assembly by aggregating the $20 \mathrm{~S}$ protein disk. We further study the binding sites of the interaction between cysteines and TMV CP by molecular docking. Further fungicidal activity tests against 14 kinds of phytopathogenic fungi revealed that these cysteine derivatives displayed broad-spectrum fungicidal activities. In this work, cysteine and its derivatives are found to be potential inhibitors against plant viruses and plant pathogens.

Supplementary Materials: The following are available online, Supplementary data (Detailed bioassay procedures for the anti-TMV and fungicidal activities; mode of action studies; copies of ${ }^{1} \mathrm{H} \&$ ${ }^{13} \mathrm{C}-\mathrm{NMR}$ spectra) can be found in the online version.

Author Contributions: Project administration, supervision, Z.W. and A.L.; writing —original draft, A.L., chemical methodology, S.Y. and T.W., biological methodology, L.S. and Y.Z.; docking studies, Z.W. All authors have read and agreed to the published version of the manuscript.

Funding: This research was funded by the Natural Science Fundation of Hebei Province (B2020202028).

Institutional Review Board Statement: Not applicable.

Informed Consent Statement: Not applicable.

Data Availability Statement: Not applicable. 
Acknowledgments: The authors also acknowledge the State Key Laboratory of Elemento-Organic Chemistry (Nankai University) for biological activity test.

Conflicts of Interest: The authors declare no conflict of interest.

Sample Availability: Samples of the compounds 8-24 are available from the authors.

\section{References}

1. Wilson, R.A.; Talbot, N.J. Fungal physiology—A future perspective. Microbiology 2009, 155, 3810-3815. [CrossRef]

2. Ji, X.F.; Guo, J.C.; Liu, Y.X.; Lu, A.D.; Wang, Z.W.; Li, Y.Q.; Yang, S.X.; Wang, Q.M. Marine-natural-product development: First discovery of nortopsentin alkaloids as novel antiviral, anti-phytopathogenic-fungus, and insecticidal agents. J. Agric. Food Chem. 2018, 66, 4062-4072. [CrossRef] [PubMed]

3. Guo, J.C.; Hao, Y.Y.; Ji, X.F.; Wang, Z.W.; Liu, Y.X.; Ma, D.J.; Li, Y.Q.; Pang, H.L.; Ni, J.P.; Wang, Q.M. Optimization, structure-activity relationship, and mode of action of nortopsentin analogues containing thiazole and oxazole moieties. $J$. Agric. Food Chem. 2019, 67, 10018-10031. [CrossRef] [PubMed]

4. Levy, S.B.; Marshall, B. Antibacterial resistance worldwide: Causes, challenges and responses. Nat. Med. 2004, 10, S122-S129. [CrossRef] [PubMed]

5. Liu, B.; Li, R.; Li, Y.A.; Li, S.Y.; Yu, J.; Zhao, B.F.; Liao, A.C.; Wang, Y.; Wang, Z.W.; Lu, A.D.; et al. Discovery of pimprinine alkaloids as novel agents against a plant virus. J. Agric. Food Chem. 2019, 67, 1795-1806. [CrossRef] [PubMed]

6. Wang, M.W.; Zhu, H.H.; Wang, P.Y.; Zeng, D.; Wu, Y.Y.; Liu, L.W.; Wu, Z.B.; Li, Z.; Yang, S. Synthesis of thiazolium-labeled 1,3,4-oxadiazole thioethers as prospective antimicrobials: In vitro and in vivo bioactivity and mechanism of action. J. Agric. Food Chem. 2019, 67, 12696-12708. [CrossRef] [PubMed]

7. Önen Bayram, F.E.; Sipahi, H.; Acar, E.T.; Kahveci Ulugöl, R.; Buran, K.; Akgün, H. The cysteine releasing pattern of some antioxidant thiazolidine-4-carboxylic acids. Eur. J. Med. Chem. 2016, 114, 334-337. [CrossRef]

8. Postma, T.M.; Albericio, F. Disulfide formation strategies in peptide synthesis. Eur. J. Org. Chem. 2014, 17, 3519-3530. [CrossRef]

9. Isidro-Llobet, A.; Álvarez, M.; Albericio, F. Amino acid-protecting groups. Chem. Rev. 2009, 109, 2455-2504. [CrossRef]

10. White, J.D.; Xu, Q.; Lee, C.S.; Valeriote, F.A. Total synthesis and biological evaluation of (+)-kalkitoxin, a cytotoxic metabolite of the cyanobacterium Lyngbya majuscule. Org. Biomol. Chem. 2004, 2, 2092-2102. [CrossRef] [PubMed]

11. Puka-Sundvall, M.; Eriksson, P.; Nilsson, P.; Sandberg, M.; Lehmann, A. Neurotoxicity of cysteine: Interaction with glutamate. Brain Res. 1995, 705, 65-70. [CrossRef]

12. Janáky, R.; Varga, V.; Hermann, A.; Saransaari, P.; Oja, S.S. Mechanisms of L-cysteine neurotoxicity. Neurochem. Res. 2000, 25, 1397-1405. [CrossRef] [PubMed]

13. White, J.D.; Lee, C.S.; Xu, Q. Total synthesis of (+)-kalkitoxin. Chem. Commun. 2003, 34, 2012-2013. [CrossRef]

14. Nagy, P.; Ashby, M.T. Reactive sulfur species: Kinetics and mechanisms of the oxidation of cysteine by hypohalous acid to give cysteine sulfenic acid. J. Am. Chem. Soc. 2007, 129, 14082-14091. [CrossRef] [PubMed]

15. Park, S.; Imlay, J.A. High levels of intracellular cysteine promote oxidative DNA damage by driving the Fenton reaction. J. Bacteriol. 2003, 185, 1942-1950. [CrossRef] [PubMed]

16. Zhu, Y.J.; Guo, X.F.; Fan, Z.J.; Chen, L.; Ma, L.Y.; Wang, H.X.; Wei, Y.; Xu, X.M.; Lin, J.P.; Bakulev, V.A. Approach to thiazole containing thiazole-containing tetrahydropyridines via Aza-Rauhut-Currier reaction and their potent biological fungicidal and insecticidal activity. RSC Adv. 2016, 6, 112704-112711. [CrossRef]

17. Liu, Y.; Jing, F.B.; Xu, Y.Y.; Xie, Y.C.; Shi, F.Y.; Fang, H.; Li, M.Y.; Xu, W.F. Design, synthesis and biological activity of thiazolidine4-carboxylic acid derivatives as novel influenza neuraminidase inhibitors. Bioorg. Med. Chem. 2011, 19, 2342-2348. [CrossRef] [PubMed]

18. El-Gazzar, A.B.A.; Gaafar, A.M.; Aly, A.S. Design, synthesis, and preliminary evaluation as antimicrobial activity of novel spiro-1,3-thiazolidine C-acyclic nucleoside analogs. J. Sulfur Chem. 2008, 29, 549-558. [CrossRef]

19. Onen-Bayram, F.E.; Durmaz, I.; Scherman, D.; Herscovici, J.; Cetin-Atalay, R. A novel thiazolidine compound induces caspase-9 dependent apoptosis in cancer cells. Bioorg. Med. Chem. 2012, 20, 5094-5102. [CrossRef]

20. Chen, H.; Yin, Q.M.; Li, C.X.; Wang, E.K.; Gao, F.; Zhang, X.B.; Yin, Z.; Wei, S.N.; Li, X.L.; Meng, M.; et al. Synthesis of C-pseudonucleosides bearing thiazolidin-4-one as a novel potential immunostimulating agent. ACS Med. Chem. Lett. 2011, 2, 845-848. [CrossRef]

21. Thalamuthu, S.; Annaraj, B.; Vasudevan, S.; Sengupta, S.; Neelakantan, M.A. DNA binding, nuclease, and colon cancer cell inhibitory activity of a $\mathrm{Cu}(\mathrm{II})$ complex of a thiazolidine-4-carboxylic acid derivative. J. Coord. Chem. 2013, 66, 1805-1820. [CrossRef]

22. Chen, L.; Zhao, B.; Fan, Z.J.; Hu, M.X.; Li, Q.; Hu, W.H.; Li, J.W.; Zhang, J.L. Discovery of novel isothiazole, 1,2,3-thiadiazole, and thiazole-based cinnamamides as fungicidal candidates. J. Agric. Food Chem. 2019, 67, 12357-12365. [CrossRef] [PubMed]

23. Chen, L.; Zhu, Y.J.; Fan, Z.J.; Guo, X.F.; Zhang, Z.M.; Xu, J.H.; Song, Y.Q.; Yurievich, M.Y.; Belskaya, N.P.; Bakulev, V.A. Synthesis of 1,2,3-thiadiazole and thiazole-based strobilurins as potent fungicide candidates. J. Agric. Food Chem. 2017, 65, 745-751. [CrossRef] [PubMed] 
24. Wang, T.N.; Yang, S.; Li, H.Y.; Lu, A.D.; Wang, Z.W.; Yao, Y.W.; Wang, Q.M. Discovery, structural optimization, and mode of Action of essramycin alkaloid and its derivatives as anti-tobacco mosaic virus and anti-phytopathogenic fungus agents. J. Agric. Food Chem. 2020, 68, 471-484. [CrossRef]

25. Zhang, B.; Li, L.; Liu, Y.X.; Wang, Q.M. Antiviral mechanism study of gossypol and its Schiff base derivatives based on reactive oxygen species (ROS). RSC Adv. 2016, 6, 87637-87648. [CrossRef]

26. Chen, P.H.; Horton, L.B.; Mikulski, R.L.; Deng, L.S.; Sundriyal, S.; Palzkill, T.; Song, Y.C. 2-Substituted 4,5-dihydrothiazole4-carboxylic acids are novel inhibitors of metallo- $\beta$-lactamases. Bioorg. Med. Chem. Lett. 2012, 22, 6229-6232. [CrossRef] [PubMed]

27. Lu, A.D.; Wang, T.N.; Hui, H.; Wei, X.Y.; Cui, W.H.; Zhou, C.L.; Li, H.Y.; Wang, Z.W.; Guo, J.C.; Ma, D.Y.; et al. Natural products for drug discovery: Discovery of gramines as novel agents against a plant virus. J. Agric. Food Chem. 2019, 67, $2148-2156$. [CrossRef]

28. Trott, O.; Olson, A.J. AutoDock Vina: Improving the speed and accuracy of docking with a new scoring function, efficient optimization, and multithreading. J. Comput. Chem. 2010, 31, 455-461. [CrossRef]

29. Zhao, H.P.; Liu, Y.X.; Cui, Z.P.; Beattie, D.; Gu, Y.C.; Wang, Q.M. Design, synthesis, and biological activities of arylmethylamine substituted chlorotriazine and methylthiotriazine compounds. J. Agric. Food Chem. 2011, 59, 11711-11717. [CrossRef] [PubMed]

30. Kappachery, S.; Paul, D.; Kweon, J.H. Effect of $\mathrm{N}$-acetylcysteine against biofouling of reverse osmosis membrane. Desalination 2012, 285, 184-187. [CrossRef]

31. Perez-Giraldo, C.; Rodriguez-Benito, A.; Moran, F.J.; Hurtado, C.; Blanco, M.T.; Gomez-Garcia, A.C. Influence of N-acetylcysteine on the formation of biofilm by Staphylococcus epidermidis. J. Antimicrob. Chemother. 1997, 39, 643-646. [CrossRef] [PubMed]

32. Stey, C.; Steurer, J.; Bachmann, S.; Medici, T.C.; Tramer, M.R. The effect of oral N-acetylcysteine in chronic bronchitis: A quantitative systematic review. Eur. Respir. J. 2000, 16, 253-262. [CrossRef] [PubMed]

33. Braga, A.L.; Appelt, H.R.; Schneider, P.H.; Rodrigues, O.E.D.; Silveira, C.C.S.; Wessjohann, L.A. New $C_{2}$-symmetric chiral disulfide ligands derived from (R)-cysteine. Tetrahedron 2001, 57, 3291-3295. [CrossRef]

34. Györgydeák, Z.; Kajtár-Peredy, M.; Kajtár, J.; Kajtár, M. Synthesis and chiroptical properties of N-acetyl-2-aryl-4-thiazolidinecarboxylic acids. Liebigs Ann. Chem. 1987, 11, 927-934. [CrossRef]

35. Soloway, H.; Kipnis, F.; Ornfelt, J.; Spoerri, P.E. 2-Substituted-thiazolidine-4-carboxylic acids. J. Am. Chem. Soc. 1948, 70, 1667-1668. [CrossRef]

36. Sutcliffe, O.B.; Storr, R.C.; Gilchrist, T.L.; Rafferty, P. Azafulvenium methides: New extended dipolar systems. J. Chem. Soc. Perkin. Trans. 1 2001, 15, 1795-1806. [CrossRef]

37. Schmolka, I.R.; Spoerri, P.E. Thiazolidine Chemistry. I. The preparation of 2-substituted thiazolidine-4-carboxylic acids. J. Org. Chem. 1957, 22, 943-946. [CrossRef] 